\title{
Mutual productivity spillovers and clusters in Eastern Europe: some empirical evidence
}

\author{
Chiara Franco ${ }^{1}$, Kornelia Kozovska ${ }^{2}$
}

August 2008

\begin{abstract}
In recent years FDI inflows towards transition countries have progressively increased, further stimulated by the entrance of some countries in the European Union. Traditional theoretical studies predict that foreign-owned companies serve as a very important source of technology transfer and productivity spillovers for the host countries. At the same time, the current applied literature finds mixed results with regards to the actual spillover effects from foreign-owned to local companies. This strand of literature on FDI is based on the fact that the MNEs' motivations for investing abroad are characterized mostly by the possibility of exploiting their pre-existing ownership advantages. However, a new approach towards MNEs as asset-seeking entities has been recently growing. This paper tests for the presence of traditional direct spillovers from foreign to domestic firm as well as of reverse spillovers from domestic to foreign firm in the context of two Eastern European countries (Poland and Romania). We have further introduced the concept of regional clusters as industrial environments theoretically more prone to induce mutual spillovers between foreign and domestic firms. In this respect, this paper examines two hypotheses: 1) whether the overall effect of direct spillover is greater for firms in clusters compared to non-clustered firms, and 2) whether the reverse spillover effect actually takes place and if clusters have any role. The econometric analysis is based on a sample of more than 7000 manufacturing firms in the two Eastern European countries. By comparing two estimation methodologies, Levinshon and Petrin, and a dynamic system GMM, we estimate a firm level production function in order to examine the presence of direct and/or reverse spillovers between foreign and domestic firms and test for the role of regional clusters in stimulating higher spillovers among its firms compared to firms which do not belong to clusters. The evidence found with reference to direct horizontal spillovers in clusters is in some cases positive confirming the hypothesis of a presence of a cluster effect. Reverse spillovers effects have been found in some cases, both in cluster and outside clusters, and even in low-tech sectors. This suggests that the presence of clusters could be a determinant in FDI localization decisions as there is a possibility of reverse spillovers, even if the host country does not possess higher technological capacity. Furthermore, clusters do seem to be industrial environments where the possibility of direct spillovers from foreign to domestic firms is considerable.
\end{abstract}

Keywords: Regional clusters, Foreign Direct Investments, Spillovers, Transition countries

JEL classification: D62, F23, O18, O57, R11

\footnotetext{
1 Ph.D. in Law \& Economics, Department of Economics, University of Bologna, Strada Maggiore 45, 40125 Bologna, Italy

e-mail: chiara.franco2@unibo.it

${ }^{2}$ European Commission - JRC, Centre for Research on Lifelong Learning (CRELL), Ispra, Italy;

Ph.D. in Law \& Economics, Department of Economics, University of Bologna, Strada Maggiore 45, 40125

Bologna, Italy

e-mail: kornelia.kozovska@jirc.it
} 


\section{INTRODUCTION}

It is widely accepted that FDI is beneficial for the economic development of nations as it introduces fresh capital, new knowledge and the possibility for spillovers (technology, production, knowledge) for the host country. This has lead to the wide support and progressive use of policies for attraction of a larger amount of FDI even though the literature on the likely impacts of FDI has been largely inconclusive and mixed for both developed, developing and transition economies (e.g. Aitken and Harrison, 1999; Javorcik, 2004). Some conditions that may affect the process, such as firms' absorptive capacities or the relative technology gap, are traditionally taken into consideration in empirical analyses. However, not enough emphasis has been put on the industrial environment in which the local firms operate, in particular, whether the presence and links with other firms may encourage or discourage spillovers. With the increasing importance given to regional clusters and cluster policies as a tool for local and regional development, the relation that these have with FDI is evident. Clusters, in fact, present an interesting case for the study of productivity spillovers from foreign firms as their essential characteristics - industrial specialization, higher concentration of specialized labor skills and geographical proximity - could favor the spillover effect due to the potential role cluster could have for attenuating the importance of large productivity gaps or low absorptive capacity.

The literature on FDI spillovers is focused on the possibility that the spillover effect runs only in one direction, i.e. from the foreign to the local firms. This approach is grounded on the OLI paradigm according to which foreign firms own higher levels of technology which is likely to spillover on local firms through various channels (labor mobility, demonstration effect, vertical linkages). The motivations which could drive such behavior have been defined by the international business literature as market-seeking, resource-seeking and efficiency-seeking (Dunning, 1993). There is a growing strand of literature focused on understanding asset-seeking motivations (e.g. Fosfuri and Motta, 1999). Only recently some papers, like Driffield (2006), have investigated whether such motivation may be a source of spillover effect. In this case the foreign firm is investing abroad in order to have access to resources not available in its home country rather than to exploit an advantage that it already possesses. In such a context clusters are important cases to analyze in order to test for reverse spillover, as they potentially have a higher concentration of knowledge and expertise and thus, could be a source of spillovers for the foreign firms as well. Contrary to studies on direct spillover effect, empirical studies on reverse spillovers, or the so called technology or knowledge sourcing activities of MNEs, have been less

common, especially so for developing or transition economies which should theoretically have 
less potential for such reverse spillovers. In fact, positive evidence for technology sourcing has been mostly found for developed countries (see De Propis and Driffield, 2006 for a study on the $\mathrm{UK}$ ) while very few attempts have been carried out for developing or transition economies ( see Wei et. al., 2008). This is due to the fact that such type of spillover should be favored by the presence of an economy with higher presence of technologically advanced sectors. However, this is not completely true, because the foreign firm may need to have access not only to higher technology but also to local knowledge. Our contribution to this debate attempts to bridge this gap and show some empirical evidence on the role that clusters could have when considering FDI spillovers. By combining information on the existence of clusters with firm-level data we created an original dataset to specifically address the problem of mutual spillovers between foreign-owned and domestic firms in clusters and outside of clusters, testing two hypotheses:

1) whether the overall effect of direct spillover is greater for firms in clusters compared to non-clustered firms and

2) whether the reverse spillover effect actually takes place and if clusters have any role.

We have chosen to study the interplay between clusters and FDI in two new EUmember states - Romania and Poland. The choice of countries for our analysis has been driven by several reasons: Eastern European countries and their experience in transition is an interesting example of economic integration and development - mid-way between developing and developed countries; Poland and Romania are of comparable size and are both new EU-member states, so they have similar membership benefits and constraints as well as similar potential attractiveness for foreign investment. However, the two countries present two different levels of advancement in the economic development and integration process as well as different paths of FDI inflows.

The article is organized in the following way: Section 2 reviews briefly the literature on spillover effects from and to foreign firms; Section 3 gives an overview of FDI determinants and the particular case of Eastern Europe, with special attention on regional clusters as a form of FDI determinant; Section 4 presents the methodology for the empirical analysis; Section 5 discusses the results obtained while Section 6 offers some conclusions and possible policy implications. 


\section{FDI SPILLOVER LITERATURE REVIEW}

FDI spillovers ${ }^{3}$ have been extensively studied. Ssome authors (Gorg and Greenway, 2004; Smeets, 2008) have summarized the existing empirical studies in an attempt to find out in which conditions spillovers are more likely to occur. Evidence for the spillover effect is not particularly clear both from theoretical and empirical point of view. The final effect on the firm's productivity varies according to various factors: the channel considered some factors that may influence the behavior of local firms (such as absorptive capacities, technology gap, geographical proximity etc.), the motivation for FDI or the behavior of subsidiaries in the host country. Moreover, there may also be reasons relative to methodological issues, such as the use of crosssection rather than panel data (Görg and Strobl, 2001) or the way the externality term is specified (Castellani and Zanfei, 2007).

In particular, the search for intra-industry spillover (horizontal effect) has often been more difficult in comparison to inter-industry spillover effect (vertical effect). For example, Javorcik (2004), analyzing the case of Lithuania, finds a positive spillover effect due to backward linkages; the same is found by Blalock and Gertler (2004) with respect to Indonesia. This result is usually associated with the channel of vertical linkage that may entail both knowledge and pecuniary spillover. The usual motivation for which the vertical effect should be positive is that MNEs would prevent the leakage of knowledge to competitive firms in the same industry where they operate, while they would be more willing to share their knowledge and raise productivity of those firms which are their buyers or suppliers.

The mixed results of the spillover evidence have been found especially in the case of transition countries: for example, Djankov and Hoeckman (2000) report negative spillovers in the case of the Czech Republic. In the same way Konings (2001) examining the case of three transition country found out negative spillovers for Romania and Bulgaria and no spillover for Poland. Some authors (Javorcik, 2002; Schoors and Van der Tool, 2002; Damjian et. al., 2003; Javorick and Spatareanu, 2008) split the effect into horizontal and vertical spillovers by finding that the latter have positive results. There are cases in which the vertical spillover effect is not significant as in the case of Merlevede and Schoors for Romania (2005) or Yudaeva for Russia (2003). However, these studies do not consider the impact of some characteristics of the external environment on the way local firms are able to take advantage of spillovers. In particular, we are interested in examining the literature that considers the regional effects of clusters. In this

\footnotetext{
${ }^{3}$ The usual definition of spillover is that of an externality: it takes place when the presence of foreign firms in the host country affects (both positively and negatively) the productivity of local firms without the possibility for MNEs to fully internalize those benefits.
} 
respect, some recent papers have analysed whether the spillover effect is more pronounced in the case of higher spatial proximity ${ }^{4}$. For example, both Resmini and Nicolini (2007) and Girma and Wakelin (2007) find that the spillover effect is positive only when a specification for the location of a firm inside a region or not is made. This same effect is found, even tough at the sectoral level, by Driffield and Propis (2006). A further reason why regional clustering is worth exploring is due to the fact that it could also be an important factor favourable to reverse spillover effects. Up to now, the usual spillover effect has been detected according to the fact that it can run in only one direction - from the MNEs to the local firms. In these cases, FDI may be carried out even though MNEs do not have any ownership advantages to be exploited, as predicted by the OLI paradigm (Dunning, 1977). However, recent papers are starting to challenge this position, suggesting that local firms may be the source of spillover effect for MNEs as well. This new stream of literature points out to the fact that MNEs do not search for places to invest only in order to exploit the existing assets at their disposal but also in order to have access or to increase those already possessed at home. This issue has been studied both on theoretical as well as empirical level (Fosfuri and Motta,1999; Neven and Siotis, 1996; Niosi 1999; Le Bas and Sierra, 2002). Empirical papers estimate the R\&D differential between countries to demonstrate the possibility of technology sourcing; in these cases technology sourcing is considered when the $R \& D$ intensity of the host country is greater than the $R \& D$ intensity of the home country (Kogut and Chang, 1991; Neven and Siotis, 1996). Theoretical studies, on the other hand, underline the fact that even a laggard firm may engage in FDI by choosing the location on the basis of the possibility of reaping technology spillover due to the proximity to local firms. These types of studies are particularly linked to the role of agglomeration economies and spatial proximity.

With regards to location motivations as determinants of spillover effect, Drieffield (2007) sheds some further light. As in previous papers (e.g. Drieffield and Love, 2003) the R\&D differentials are taken as proxy of $R \& D$ endowment between the two countries and, in his empirical estimation he does not find any evidence of spillover coming from asset seeking motivations. Instead, considering always the case of UK, the paper by Drieffield and de Propis finds out that the possibility of spillover effect is higher depending on whether the firm is located inside a cluster or not. It is important to note, however, that MNEs could be localized in proximity to clusters for reasons not necessarily related to the higher technological base, for example low cost labour, specialized labour resources, tax incentives, market presence. They can theoretically find favorable environment in clusters and could also expect to benefit from reverse

\footnotetext{
${ }^{4}$ It should be pointed out, however, that the literature on localized knowledge spillover is more extensive that the one related only to the spillover effect coming from FDI.
} 
spillovers as clusters often times possess unique knowledge, expertise and human resources, not necessarily always related to higher technology but for example also to knowledge of the local market. In fact, the main characteristics of clustering could offer benefits to foreign firms which go beyond the pure technological sourcing, and can thus be available also in countries which do not possess superior R\&D endowment. Even though there is a growing number of studies on the possibility of having access to location-specific advantages, there is a lack of empirical estimates that may be able to understand whether this is a growing trend and whether it may vary according to geographical and industrial contexts. The point of departure for this type of argument is relative to the fact that as Porter (1998) says, clusters could lead to higher competitiveness for the firms within them due to the increasing productivity, higher innovation drive, availability of specialised resources and stimulating co-opetition environment. The assumption is that many firms perform better in a cluster than they do outside a cluster.

Reverse spillovers are considered more likely where the possibility of spillovers from local firms is greatest and this occurs mostly in cases where the technological level of the host country is higher. It is for this reasons that only few papers analyse the reverse spillover effect in developing countries. The only contribution that tries to examine this issue is the paper by Wei, Y. et al. (2008). It argues that local knowledge of the context contributes to the productivity increase of multinationals and finds evidence for mutual spillovers between local Chinese manufacturing firms and foreign firms.

\section{FDI DETERMINANTS AND REgIONAL CLUSTERS}

As it has been discussed in the previous section, the importance of FDI for the economic development of host countries has been given support for a long time through many theoretical and empirical studies. The OLI paradigm gives a theoretical backbone to the study of FDI motivations. It consists of three categories of factors which simultaneously motivate FDI ownership-specific advantages $(\mathrm{O})$ for firms to operate abroad (ex. intangible assets or property rights), location-specific advantages (ex. differences in natural endowments, transport costs, macroeconomic stability, cultural factors, government regulations) to invest in the host rather than the home country (L) and benefits arising from internationalisation-specific advantages (I), i.e. exploitation of imperfections in external markets. In the context of these categories of FDI motivations, we have three broad categories of FDI determinants - market- (horizontal FDI), trade- and human-capital related motives. However, there is also the possibility that FDI is determined by the desire to acquire resources (natural resources, raw materials, or low-cost inputs such as labour) at lower cost (resource-seeking) not available in the home country. Such 
also called vertical or export-oriented FDI involves the relocation of parts of the production chain to the host country. This type of FDI is often times driven by the lower cost of labour in the manufacturing sector while availability of natural resources such as oil and gas drives resource-oriented FDI. Motivation for FDI can be also the desire to gain from the common governance of geographically dispersed activities in the presence of economies of scale and scope or the so-called efficiency-seeking investment (Kinoshita and Campos, 2003). Bevan and Estrin (2000) find proof for such kind of FDI in the first wave of EU accession countries as the prospects of EU membership have assisted in the establishment of regional corporate networks. All these factors are also influenced by some more general aspects such as political stability and more concretely the frequency of changes in a country's legal policies and administrative barriers (OECD, 1994) as well as possible FDI incentives such as, free economic zones, tax beaks, etc.

There is also the possibility that FDI is motivated by the need of acquiring technology or qualified human capital resources not available at home. Such asset-seeking FDI could be driven by, for example, agglomeration economies. Such FDI determinants are closely related to the location-specific advantages considered by foreign companies. New investors tend to concentrate in locations with already establishment investors which can lead to positive externalities such as knowledge spillovers, specialised labour and intermediate inputs from the surrounding companies. Or often times they become themselves a centre for an agglomeration of local suppliers, clients, etc. Most of the empirical studies on the issue may be found for developed countries and specifically for the US (Wheeler and Mody, 1992; Head et al, 1995) but only very few studies have been done on transition and developing countries.

In order to understand whether the asset seeking motivation may be found even for Eastern Europe we should have a look at the possible determinants of FDI in those countries. Various studies on the specific determinants of FDI in transition countries have been done among which Lankes and Venables(1996), Boros-Tostila (1999), Resmini (2000), Woodward et al. (1997). Transition countries have some peculiar characteristics distinguishing them from both developed and developing countries such as high-skilled labour, relatively developed infrastructure, favourable geographical position and improving institutional structures. The transition started more or less simultaneously in almost all countries which however, differed substantially in initial conditions, inherited institutions, income levels and reform paths (Kinoshita and Campos, 2003). During the transition period FDI has consistently been viewed as a general solution for achieving fast growth with the expectation it will bring various benefits to the local economies, most importantly fresh capital and technological change. The presence of industries and industrial experience which differentiated transition from developing countries 
was found a misleading factor for higher expectations on the absorptive capacity by some authors (Kornai, 1992; Poznanski, 2001). In fact, the socialist system was structured in such a manner that growth was a result of central resource transfers and not on entrepreneurial efforts. This led to almost absent local innovation and technological change, any technological innovation for most of the socialist period arrived generally via the acquisition of machinery. As there was no price premium and no free entry in the economy, under-investment in new industries and services was a common phenomenon. Some authors question the advantages which transition countries were supposed to have in comparison to developing countries as most such advantages, inherited firm-specific assets, inherited accumulated human capital, have proven unsubstantial. Konings (2001) and Jensen (2004) find that transition countries experience similar difficulties in successfully benefiting from FDI.

Most studies find that traditional FDI determinants are relevant in transition countries with market-seeking as the most important while nature resources-seeking is relative to countries with significant natural resources, mostly CIS countries. Along with these traditional determinants, an important role is played by transition-specific ones - corruption level, privatisation method, legal system development. Bevan et al. (2004) find that legal development and foreign exchange and trade liberalisation are the most important aspects of institution building affecting FDI inflows. Kinoshita and Campos (2003) find that for Eastern European and Baltic countries institutions, agglomeration economies and the abundant natural resources are the main determinants for FDI, overriding the importance of other variables. Other important drivers of FDI in transition countries have been identified as the need to secure market access, opportunity perceived in the participation in large scale privatization processes, and the degree of political and economic stability. Habuda and Szalavetz (2000) emphasize the strong absorptive capacity of Central European countries, based on the high level of human capital. In fact, the relative good performance of local technical staff has lead to a raising interest of MNEs in local R\&D potential.

The graphs below show the rate of FDI flows in Eastern European countries in the period 1990 - 2006. Differences in FDI are evident with Central European countries on the forefront while Bulgaria and Romania have been catching up in the last couple of year. The second graph isolates the inflows in Poland and Romania where we can note that Poland has been more successful in attracting larger amounts of FDI, but Romania has had a continuous and sharp progress. 
Graph 1. FDI inflows in Eastern Europe (1990-2006)

FDI inflows 1990-2006

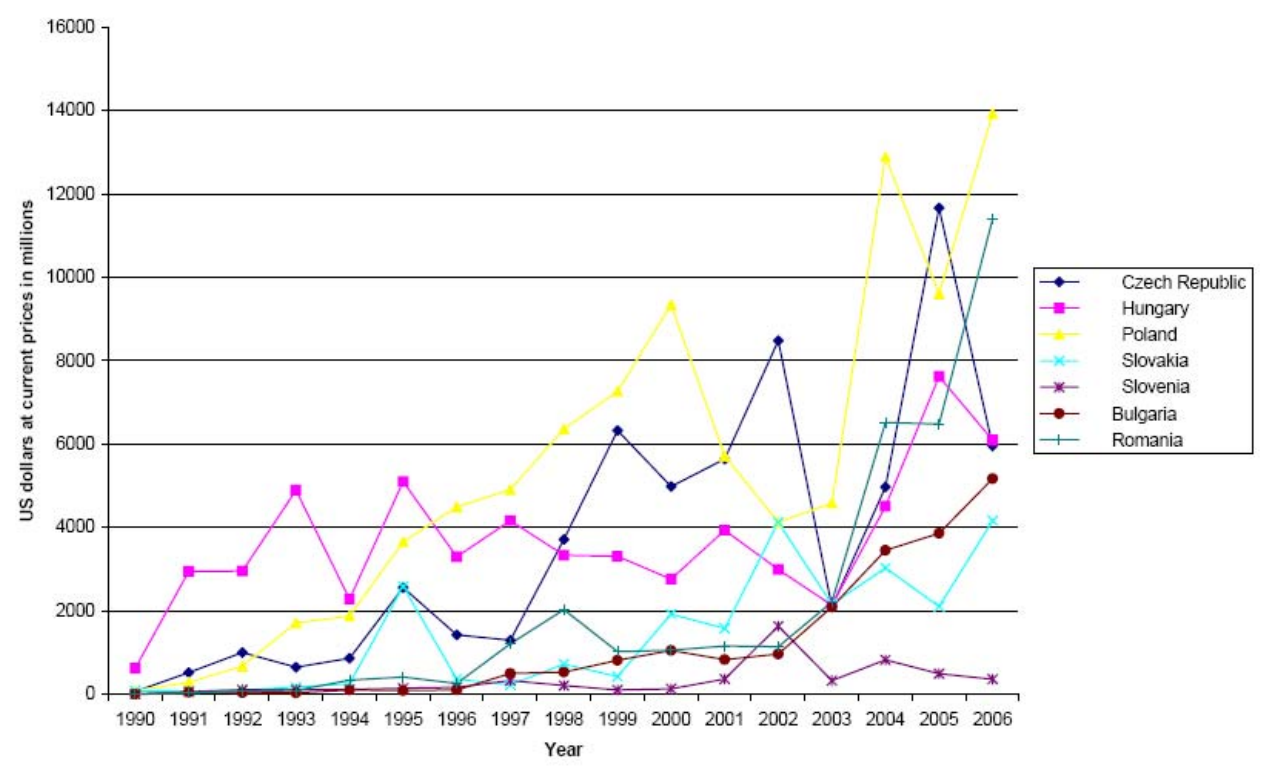

\section{Graph 2. FDI inflows in Poland and Romania (1990-2006)}

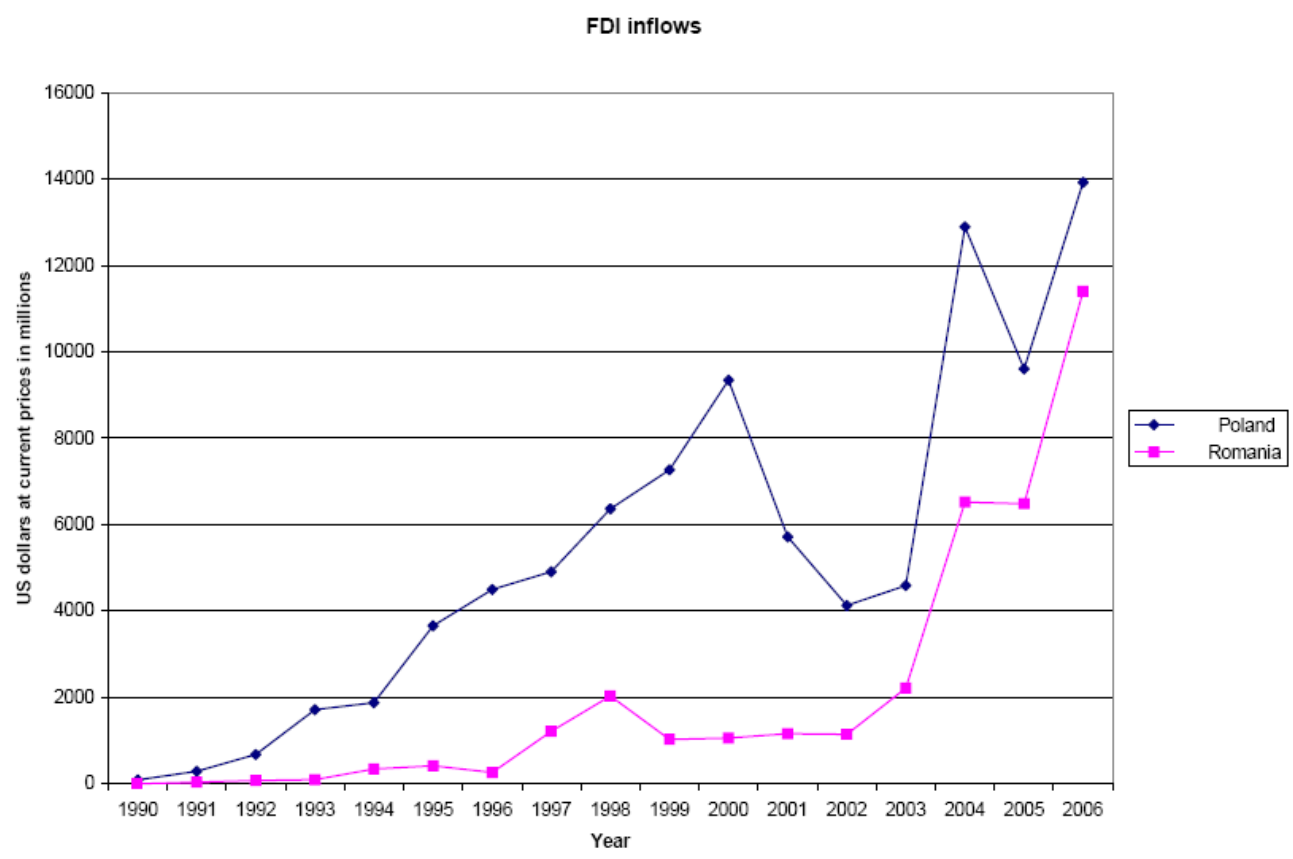

Agglomeration economies refer to the positive externalities and economies of scales associated with spatial concentration of economic activities and co-location of related production 
facilities (Smith and Florida, 1994). Agglomeration effects due to the presence of specialized service suppliers, skilled labor, location related reputation effects and the development of clusters could have an important role in the location attractiveness to foreign investments (Porter, 1990; Dunning, 1998). Porter (1990) defines clusters as geographic concentrations of firms in related industries, including competitors, customers, a thick bed of suppliers and firms in related industries and specialized factor pools, including skilled labor and local research, development or design facilities. In this study, we have concentrated on regional clusters as both MNE activity and absorptive capacity are better captured on the cluster level (Gugler and Brunner 2007). The attention which clusters have received in recent years, through the increased interest in the work of Porter as well as the proliferation of cluster initiatives around the world, shows a growing attention towards the localization factor in firm organization. In fact, potentially due to its characteristics firms part of a cluster should be able to have higher absorptive capacity than single firms which do not belong to agglomeration economies.

The link between clusters and the absorptive capacity of host firms has not been examined in detail and this study tries to shed some light on this interesting and challenging argument, proposing the hypothesis that proximity and networking enhance the absorptive capacity of domestic firms and thus the positive effects of FDI while at the same time creating favorable conditions for reverse spillovers as well. Regional clusters provide proximity benefits and the possibility of strong social capital presence. They have also been found to assist small and medium enterprises to compete in global markets (Brown and Bell, 2001), thus increasing the productivity and export capacity of local SMEs. As Belussi (2006) points out a growing strand in international business literature links clusters to MNEs as FDI inflows and subsidiary development can be motivated by the competence and knowledge endowment created in clusters. This could then lead to direct spillovers to the domestic suppliers and other neighboring firms. At the same time, however, MNEs in clusters could have the potential of benefiting from reverse spillovers as even if the technology level of firms in a cluster might be lower, the geographical proximity and the possibility of a limited geographical mobility of labor, guaranteeing well-qualified workers, good knowledge of the market and already established networks, could still be factors from which the foreign firm can extract benefits. Furthermore, $\mathrm{He}$ (2002) argues that MNEs suffer from adverse information asymmetry and experience internal and external uncertainties when settling in host economies and suggests that agglomeration economies could attenuate these difficulties. In an empirical study of FDI in 200 Chinese cities over two years, he finds evidence for FDI being determined by agglomeration economies and information costs as supposed to traditional production costs. In fact, a proof of the benefit of 
clusters for both direct and reverse spillovers can suggest that the usual hypothesis for the technology and R\&D difference as essential to the possibility of benefiting from spillovers could be challenged by the presence of clusters and its importance could become less significant. This could add a further motivation for foreign firms to locate themselves in or close to clusters abroad, and especially so in less-technologically advanced or developing countries. In this context, we consider that transition countries present an interesting environment for testing such processes.

\section{EMPIRICAL ANALYSIS}

\subsection{Description of datasets}

Our analysis draws on two sets of data: the first allows for the identification of clusters in two Eastern European countries (Poland and Romania) using the European Cluster Observatory (ECO) database while the second, the Amadeus database, contains firm level data consisting of annual company accounts for all incorporated firms in the manufacturing sectors of the two countries for the time period $2000-2006$.

The Cluster Observatory Mapping, made available at the end of 2007, presents a unique comparable database on clusters across Europe and especially for Eastern European countries, where studies on clusters are still in their initial phases, and, as such is one of few such sources of systematic data on the type and location of clusters in the new member states. The Cluster Mapping database ${ }^{5}$ is built through the intersection of regions and sectors in Europe, combining the two dimensions of geography and industry by statistically tracing agglomerations of employment in co-located industries, defined as statistical regional clusters, across Europe. Regions are considered at the NUTS 2 level while employment data is considered for the 4-digit industry level. The cluster definition used by ECO is based on the definitions ${ }^{6}$ developed by Michael Porter in his similar analysis of the geographical distribution of economic activity across the US ${ }^{7}$. In order to evaluate whether the presence of employment in specific industries

\footnotetext{
5 The European Cluster Observatory database can be found under Cluster mapping on the website of the project www.clusterobservatory.eu. The project offers unique compilation of data on geographical patterns of specialisation across cluster categories, national and regional portfolios of clusters, cluster organisations, and national and regional policies and programmes related to innovation and clusters.

${ }^{6}$ Porter identifies geographic distribution of employment, relates it to the appropriate definition of geographic regions (NUTS 2 level for the EU), obtaining employment data at the highest available level of industry granularity (mostly NACE 4-digit level).

${ }^{7}$ It should be noted that cluster definitions do not always reflect the true underlying linkages between industries in the new member states as trade barriers and other political interferences could have significantly influences current location patterns.
} 
belonging to a cluster category in a specific region has a sufficient specialized critical mass to develop the linkages and spillovers which can lead to positive economic impacts, all clusters have been assigned from one (weak clusterisation) to three (very strong clusterisation) stars. For our sample of countries we have concentrated exclusively on clusters with two or three starts. The Cluster Observatory Mapping exercise presents a unique comparable database on clusters across Europe and especially for Eastern European countries, where studies on clusters are still in their initial phases, and as such is one of few such sources of data on the type and location of clusters in the new member states.

The Amadeus database, published by Bureau Van Dijk, includes firm-level accounting data in standardized financial format. Besides financial information, it also contains industry classification, the regional location of each firm and detailed ownership information, including the names and country(s) of origins of all block shareholders which has allowed us to label each firm as domestic or foreign. We have used the accepted definition of foreign-owned firms as firms with a minimum ownership of at least $10 \%$ of the shares by a foreign investor ${ }^{8}$. We have dropped from the sample all firms with missing information on the nationality of the ownership. Similar to Resmini and Nicolini (2007) we have employed this methodology in order to avoid overestimation of both direct and reverse spillovers.

For each country we have identified all 2-3 star clusters from the European Cluster Observatory database, aggregating them in low-tech and high-tech according to the OECD classification 9 for a total of 81 clusters. For Poland we have 29 low-tech and 9 high-tech clusters while for Romania - 35 low-tech and 8 high-tech. For each cluster, the relative firm level data for the period from 2000 to 2006 available from the Amadeus database has been identified, using the relative NACE codes and the respective country's geographical location/region. In order to be able to do a comparative study between firms in clusters and outside clusters, the information for all firms in the given country which do not belong to the respective clusters and geographical areas but are within the same cluster categories, as defined by the combination of NACE codes, have been extracted from Amadeus. The dataset currently provides information on a total of more than 7000 firms belonging to clusters in Poland and Romania for the period 2000-2006. The use of both databases gives systematic data across countries and allows for a comparative study. Many previous studies on clusters have been mainly done either with especially created ad-

\footnotetext{
${ }^{8}$ This is the standard definition provided by OECD and IMF.

9 See Hatzichronoglou, T. (1997). "Revision of the High-Technology Sector and Product Classification." STI Working Paper 1997/2, OECD, Paris
} 
hoc datasets or with data available on national/regional level but not easily comparable with other countries. Table 1 gives an overview of our sample ${ }^{10}$ :

Table 1.

\begin{tabular}{|c|c|c|c|c|c|c|c|c|c|}
\hline & & & \multicolumn{3}{|c|}{ foreign firms } & \multicolumn{3}{|c|}{ domestic firms } & \multirow[b]{2}{*}{ Total } \\
\hline & & & No firms & R\&D mean & TFP mean & No firms & R\&D mean & TFP mean & \\
\hline \multirow{5}{*}{$\begin{array}{l}\text { 루 } \\
\frac{\pi}{0} \\
\frac{0}{0}\end{array}$} & \multirow{5}{*}{$\begin{array}{l}\text { high-tech } \\
\text { low-tech }\end{array}$} & clustered & 244 & 461.90 & 35.76 & 424 & 236.82 & 3.17 & 668 \\
\hline & & non-clustered & 939 & 602.79 & 22.83 & 1491 & 350.64 & 13.18 & 2430 \\
\hline & & clustered & 261 & 813.78 & 6.88 & 829 & 298.74 & 5.62 & 1090 \\
\hline & & non-clustered & 329 & 411.05 & 11.87 & 648 & 259.01 & 8.55 & 977 \\
\hline & & TOTAL & 1773 & & & 3392 & & & 5165 \\
\hline \multirow{5}{*}{ 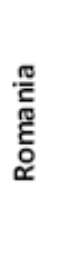 } & high-tech & clustered & 90 & 148.76 & 1.10 & 119 & 28.10 & 0.98 & 209 \\
\hline & & non-clustered & 281 & 1434.98 & 84.56 & 358 & 77.94 & 17.36 & 639 \\
\hline & low-tech & clustered & 671 & 33.29 & 0.87 & 399 & 10.39 & 0.61 & 1070 \\
\hline & & non-clustered & 391 & & & 2 & & & 393 \\
\hline & & TOTAL & 1433 & & & 878 & & & 2311 \\
\hline
\end{tabular}

We can note that Poland has a higher number of foreign firms in high-tech clusters while the same is true for Romania in low-tech clusters. This confirms the fact that the two countries have different technological specializations. Possible implications for FDI motivations can be that Poland has more asset-seeking FDI, while market or resource-seeking FDI may be prevalent in the case of Romania. However, if we divide between cluster and non-cluster, we can observe that the absolute number of foreign firms is higher in both cases for low-tech sectors. This can imply that motivations for MNEs, investing in those countries, are not only those of exploiting their technology already possessed at home or that of searching for high technology not possessed, but also that of searching assets in low-tech sectors.

However, simply looking at the number of foreign firms does not allow us to make any hypothesis with regards to the direction of the spillovers. More information can be obtained from looking at the descriptive statistics (simple mean) of variables like R\&D and productivity both for foreign and domestic firms. We measure Total Factor Productivity (TFP) as the residuals obtained by first estimating a log-linear transformation of a Cobb-Douglas production function:

$$
\ln Y_{i j t}=\alpha+\beta_{1} \ln K_{i j t}+\beta_{2} \ln M_{i j t}+\beta_{3} \ln L_{i j t}+\varepsilon_{i j t}
$$

\footnotetext{
${ }^{10}$ For Romanian low-tech non-clustered firms, we have only two foreign firms in the sample and thus, we have excluded the category from further estimations.
} 
by using the Levinson and Petrin (2003) estimator. This estimation technique takes into consideration the fact that the productivity known by the firm but not by the econometrician may affect the input decision ${ }^{11}$. We measure output $(\mathrm{Y})$ with sales, capital stock $(\mathrm{K})$ is proxied by the declared value of tangible fixed assets in the firm, material inputs $(\mathrm{M})$ are proxied by material costs, labour $(\mathrm{L})$ is measured by the number of employees. All values are deflated by the relative annual country GDP deflator. R\&D expenditure at the firm level is proxied by the declared value of intangible assets.

From the mean statistics we note that foreign firms in both countries are always more productive than local firms. Polish firms (both foreign and domestic) are more productive than Romanian firms and possess a higher level of R\&D (except for the case of high-tech nonclusters). This confirms the fact that the technological level of the two countries is quite different. According to the technology backwardness approach, this would mean that foreign firms are investing abroad to exploit their own advantages and for this reason we expect a positive effect on domestic firms for the direct spillover effect and negative or null for the reverse spillover effect. This should be particularly true for the case of Poland in high-tech clusters where the difference of TFP between foreign and local firms is quite high in contrast with the other cluster cases, especially in low-tech sectors. Thus, we can make the hypothesis that reverse spillover could be possible (especially in low-tech sectors). The case of non-clusters shows a large difference in TFP levels and implies that reverse spillovers are improbable while there could be direct spillovers. We also consider R\&D levels which may be considered as a proxy of absorptive capacity for both foreign and domestic firms and of the level of their respective technological activity. Similarly, foreign firms have higher R\&D levels than local firms. In particular, both foreign and local firms in the Polish low-tech sectors outperform those in the high-tech sectors. This could suggest that even in low-tech sectors the possibility of reverse spillover may be high.

\subsection{Methodology}

The baseline model usually employed to test the spillover effect is the following:

$$
\ln Y_{\mathrm{ijt}}=\alpha+\beta_{1} X+\beta_{2} Z+\varepsilon_{\mathrm{ijt}}
$$

\footnotetext{
${ }^{11}$ Levinsohn and Petrin rely on intermediate input to proxy for unobserved heterogeneity rather than on investment decision like Olley and Pakes (1996).
} 
where $\mathrm{Y}$ is the log of output (it could be measured in different ways, such as value added, labor productivity or sales), $\mathrm{X}$ is the spillover variable (measured as the share of output of foreign firms on domestic firms at the sectoral ${ }^{12}$ level) and $\mathrm{Z}$ is usually a set of variables that take into consideration some conditionalities, the most important ones being the absorptive capacities and the technology gap. There is a great debate in the literature on the role of these two variables in mediating the final spillover effect combined with a wide variety of ways to measure and interpret them theoretically. The debate between the "technological accumulation" of Cantwell (1989) and the "catching - up" hypothesis of Findlay (1978) implies two different position on the role played by the technology gap between foreign and domestic firms. In the first case, a smaller gap is considered beneficial for local firms; in the second case, a larger gap is considered to be the source of greater spillover effect. With regards to the role of absorptive capacity, the evidence is mostly in favor of a positive relationship between its level and the level of spillover (see, for example, Girma, 2005), implying that all firms need a minimum amount of absorptive capacity in order to be able to capture some spillover effect.

For these reasons, in order to have some insight on the signs of both direct and reverse spillover, we estimate the baseline model by only adding an R\&D variable which measures absorptive capacity.

$$
\ln \mathrm{TFP}_{\mathrm{ijt}}=\alpha++\beta_{1} \mathrm{SP}_{\mathrm{ijt}}+\beta_{2} \mathrm{RD}_{\mathrm{ijt}}+\varepsilon_{\mathrm{ijt}}
$$

The dependent variable is the log of TFP, estimated with the Levinshon and Petrin methodology explained above. The subscript $\mathrm{i}$ and $\mathrm{t}$ refer to firm and year, respectively, while $\mathrm{j}$ refers to the sector. Our expectations for this baseline estimation is that we find positive results for direct spillovers in both high-tech and low-tech clusters, even in the case where the level of absorptive capacity is not significant. This is motivated by the fact that being part of a cluster, we expect that flows of knowledge inside the cluster and spillover between and within firms, even though not directly observable, may contribute to enhance the productivity of domestic firms and the way the R\&D is "used" to take advantage of the spillover effect. It may be true even in the case of foreign firms even though the way of reasoning is different because we consider that being inside a cluster may favor the absorption of spillover coming from domestic firms due to this cluster effect.

In our analysis we go beyond this model, adding further control variables:

12 The term "sector" is intended as the aggregate of all high-tech or low-tech clusters, respectively, in the given country. 


$$
\begin{gathered}
\operatorname{LnTFP}_{\mathrm{ijt}}=\alpha+\beta_{1} \mathrm{SP}_{\mathrm{jt}} * \mathrm{RD}_{\mathrm{ijt}}+\beta_{2} \mathrm{RD}_{\mathrm{ijt}} * \mathrm{RDregional}_{\mathrm{jt}}+\beta_{3} \mathrm{RDgap}_{\mathrm{ijt}} * \mathrm{SP}_{\mathrm{jt}}+\beta_{4} \\
\operatorname{TFPgapc}_{\mathrm{ijt}} * \mathrm{SP}_{\mathrm{jt}}+\beta_{5} \operatorname{TFPgap}_{\mathrm{ijt}} * \mathrm{SP}_{\mathrm{jt}}+\beta_{6} \operatorname{TFPgaploc}_{\mathrm{ijt}} * \mathrm{SP}_{\mathrm{jt}}+\beta_{7} \operatorname{TFPgap}_{\mathrm{ijt}} * \mathrm{RD}_{\mathrm{ijt}} \\
+\beta_{8} \operatorname{TFPgaploc}_{\mathrm{ijt}} * \mathrm{RD}_{\mathrm{ijt}}+\beta_{9} \operatorname{TFPgapcl}_{\mathrm{ijt}} * \mathrm{RD}_{\mathrm{ijt}}+\eta_{\mathrm{jt}}+\varepsilon_{\mathrm{ijt}}
\end{gathered}
$$

\begin{tabular}{|c|c|c|}
\hline Variables & Definition & Source \\
\hline Sales & Log of sales in firm i at time $t$ in sector $\mathrm{j}$ & Amadeus \\
\hline Capital & Log of tangible assets & Amadeus \\
\hline Labor & Log of number of employees & Amadeus \\
\hline Material costs & Log of materials costs & Amadeus \\
\hline$R \& D$ & Intangible assets & Amadeus \\
\hline$R \& D$ regional & $\begin{array}{l}\text { the average of the R\&D expenditure of the regions part of the } \\
\text { high-tech/low-tech clusters/non-clusters, respectively }\end{array}$ & Eurostat \\
\hline Horizontal spillover (sp) & $\begin{array}{l}\text { the share of foreign/domestic firm's output to total "sector" } \\
\text { output }\end{array}$ & Amadeus \\
\hline RD gap & $\begin{array}{l}\text { the difference between the R\&D of each single firm and the } \\
\text { R\&D average of foreign/local firms in clusters/non-clusters in } \\
\text { high-tech/low-tech sectors, respectively }\end{array}$ & $\begin{array}{c}\text { Amadeus, Authors' } \\
\text { own calculations }\end{array}$ \\
\hline TFPgap & $\begin{array}{l}\text { the difference between the TFP of each single firm and the } \\
\text { TFP average of foreign/local firms in clusters/non-clusters in } \\
\text { high-tech/low-tech sectors, respectively }\end{array}$ & $\begin{array}{c}\text { Amadeus, Authors' } \\
\text { own calculations }\end{array}$ \\
\hline TFPgapcl & $\begin{array}{l}\text { the difference between the TFP of each single firm and the } \\
\text { TFP average of the cluster, high-tech or low-tech, cluster/non- } \\
\text { cluster, respectively }\end{array}$ & $\begin{array}{c}\text { Amadeus, Authors' } \\
\text { own calculations }\end{array}$ \\
\hline TFPgaploc & $\begin{array}{l}\text { the difference between the TFP of each firm and the } \\
\text { corresponding average TFP of foreign/local firms in } \\
\text { clusters/non-clusters in high-tech/low-tech sectors, } \\
\text { respectively }\end{array}$ & $\begin{array}{c}\text { Amadeus, Authors' } \\
\text { own calculations }\end{array}$ \\
\hline
\end{tabular}

The following table gives an overview of the way the variables have been constructed:

The variable whose sign is of crucial importance for the occurrence of the spillover effects is the one related to the interaction of the spillover effect with the firm R\&D. Following our discussion, for clusters we can make the hypothesis that the $\mathrm{R} \& \mathrm{D}$ value is positively correlated with the possibility of grasping the spillover effect due to the cluster effect already defined. We further add a R\&D gap variable to measure whether being relatively far from the average $R \& D$ of the cluster (or non-cluster) has any significance as to the possibility of capturing the spillover effect. With regards to direct spillovers it measures how much each domestic firm with respect to all other firms can benefit from the spillover effect; when looking at the reverse spillover effect, it measures the spillover impact on foreign affiliates. These expectations should be valid especially for high-tech sectors. 
We have also inserted variables relative to the technology gap. The spillover variable is interacted with a technology gap measure that is measured along three dimensions: the first is the distance of the TFP of each firm from the mean of the TFP of all foreign or local firms, respectively (TFP gap); the second is a measure of the distance between the TFP of each firm (local or foreign) from the mean of the TFP of foreign or local firms (TFP gaploc); the third variable is relative to the TFP gap measured as the distance between the TFP of each firm and the average TFP of the cluster as a whole or non cluster (TFP gapcl). All variables are always divided according to the distinction low-tech/high-tech and cluster/non-cluster. They should take into account whether the so called "technological distance" is significant for absorbing spillover effects. The construction of the measure of this gap is driven by the consideration that the distance from the mean of each single variable is more important than what is the relative difference in productivity between firms. We measure this variable both for domestic and foreign firm as it may be reasonable that the level of technology of a foreign firm may matter for reverse spillovers. Thus, the expected signs as shown in Table 3 are all positive for direct spillover in the case of clusters, while, always considering clusters but for the case of reverse spillover we expect positive signs for low-tech and negative for high-tech sectors. In fact, spillovers in technologically advanced sectors from domestic to foreign firms when the host country is not necessarily at the forefront of technology development could be less probable, while spillovers in low-tech sectors could be more likely as they could consist of other technologically unrelated knowledge/information/skills transmitted.

Furthermore, we interact the three different TFP gap measures with the firm R\&D. There is not enough consideration given in previous studies to the fact that absorptive capacity and technology gap may be not only related but they can act simultaneously. In particular, for both reverse and direct spillover we expect that if foreign or domestic firms are in a cluster they will be able to exploit better their R\&D expenditure or that their technology gap will be less detrimental due to what we define as a cluster effect.

The last variable we have included is the interaction between the $\mathrm{R} \& \mathrm{D}$ of each single firm and a measure of the regional $R \& D$ investment in order to account for the fact that $R \& D$ may capture spillover effects more efficiently the higher is the level of the R\&D of the region where the firm is located.

The following table presents a summary of the expected signs of all variables: 
Table 3.

\begin{tabular}{|c|c|c|c|c|c|c|c|c|}
\hline \multirow{4}{*}{ Variables } & \multicolumn{8}{|c|}{ Expected sign } \\
\hline & \multicolumn{4}{|c|}{ Direct spillovers } & \multicolumn{4}{|c|}{ Reverse spillovers } \\
\hline & \multicolumn{2}{|c|}{ Clusters } & \multicolumn{2}{|c|}{ Non-clusters } & \multicolumn{2}{|c|}{ Clusters } & \multicolumn{2}{|c|}{ Non-clusters } \\
\hline & High-tech & Low-tech & High-tech & Low-tech & High-tech & Low-tech & High-tech & Low-tech \\
\hline $\mathrm{SP} * \mathrm{RD}$ & + & + & $-/ 0$ & $-/ 0$ & - & + & - & - \\
\hline RDgap*SP & - & - & -10 & -10 & + & - & -10 & -10 \\
\hline TFPgap*SP & + & + & - & - & - & + & -10 & -10 \\
\hline TFPgapLOC*SP & + & + & - & - & - & + & $-/ 0$ & $-/ 0$ \\
\hline TFPgapCL*SP & + & + & - & - & - & + & -10 & $-/ 0$ \\
\hline TFPgap*RD & + & + & $+/ 0$ & +10 & + & + & $-/ 0$ & -10 \\
\hline TFPgapLOC*RD & + & + & $+/ 0$ & +10 & + & + & -10 & -10 \\
\hline TFPgapCL*RD & + & + & $+/ 0$ & $+/ 0$ & + & + & -10 & -10 \\
\hline RD*RDregional & + & + & $+/-$ & + +/- & + & + & $+/-$ & $+/-$ \\
\hline
\end{tabular}

We estimate the model using the residuals of the first step estimation as a dependent variable. The TFP obtained from the first step estimation carried out with the methodology of Levinshon and Petrin (2003) is then used as depended variable to estimate the model (4) previously described. The estimation method chosen at this stage is the OLS using first difference to eliminate any unobservable firm specific effects.

There is no general agreement in the FDI literature on the best estimation technique for spillover effects as all of them have drawbacks and disadvantages. We use two different techniques in order to be able to compare their output and capture the different elements they introduce in their relative models - a first difference model and a system GMM technique introduced by Blundell and Bond (1999) which allows us to introduce in the model some of form of dynamics. In particular, we put in the first lag of the dependent variable to capture the persistence in sales. In order to account for endogeniety of inputs and of the dependent variable, we use as instruments the third lag of those variables ${ }^{13}$ : we use earlier instruments dated $\mathrm{t}-3$ for the equations in first differences and instruments dated t-2 for the equations in level. The Hansen test gives indication as to the validity of the instruments.

$$
\begin{gathered}
\ln Y_{\mathrm{ijt}}=\alpha+\beta_{1} \ln K_{\mathrm{ijt}}+\beta_{2} \ln \mathrm{M}_{\mathrm{ijt}}+\beta_{3} \ln \mathrm{L}_{\mathrm{ijt}}+\beta_{4} \ln \mathrm{Y}_{\mathrm{t}-\mathrm{ijjt}}+\beta_{5} \mathrm{SP}_{\mathrm{jt}} * \mathrm{RD}_{\mathrm{ijt}}+ \\
\beta_{6} \mathrm{RD}_{\mathrm{ijt}} * \operatorname{RDregional}_{\mathrm{jt}}+\beta_{7} \operatorname{RDgap}_{\mathrm{ijt}} * \mathrm{SP}_{\mathrm{jt}}+\beta_{8} \operatorname{TFPgapc}_{\mathrm{ijt}} * \mathrm{SP}_{\mathrm{jt}}+\beta_{9} \operatorname{TFPgap}_{\mathrm{ijt}} * \mathrm{SP}_{\mathrm{jt}} \\
+\beta_{10} \operatorname{TFPgaploc}_{\mathrm{ijt}} * \mathrm{SP}_{\mathrm{jt}}+\beta_{11} \operatorname{TFPgap}_{\mathrm{ijt}} * \mathrm{RD}_{\mathrm{ijt}}+\beta_{12} \operatorname{TFPgaploc}_{\mathrm{ijt}} * \mathrm{RD}_{\mathrm{ijt}}+ \\
\beta_{13} \operatorname{TFPgapcl}_{\mathrm{ijt}} * \mathrm{RD}_{\mathrm{ijt}}+\eta_{\mathrm{jt}}+\varepsilon_{\mathrm{ijt}}
\end{gathered}
$$

\footnotetext{
13 We use the third lag instead of the second lag because in some cases the Hansen test rejects the validity of instruments. In some cases the Hansen test rejects even these types of instruments. For this reasons we use another lag (or two). Only in the case of direct spillover in Romania (low-tech, cluster), the Hansen test is rejected even with further lags of instruments.
} 
The system GMM estimation technique is based only on one step. We have chosen it for comparison because two-steps estimation of the effect of FDI on the productivity of domestic firms may result in a problem of omitted variables. The GMM estimation may be applied in two ways: using difference GMM (diff-GMM), which uses lagged levels as instruments for firstdifferenced equation, or using system GMM (sys-GMM). As shown by Arellano and Bover (1995), the difference GMM technique may have problems with weak instruments due to the presence of lagged level instruments. Arellano and Bond (1991), and Blundell and Bond (1998, 1999) suggest that an application of the sys-GMM estimators is a more appropriate approach to dynamic panel data than using the diff-GMM estimators because of greater efficiency. This same methodology has been used by other studies studying FDI spillover effects: among others Harris (2002) and Harris and Robinson (2003).

We also compare the results with an OLS estimation because, even though OLS produces biased and inconsistent results ${ }^{14}$, it can convey information about statistical associations among our variables of interest.

\section{RESUlts}

\subsection{Benchmark model results}

We analyze the benchmark model, because even though it considers only the measure of spillover effect and the firm level absorptive capacity, it may give some insights as to what are the results to be expected in the estimation of the following models. We expect to find positive results for direct spillovers, especially in the case of clusters, while no specific hypothesis may be made about the sectors in which they should occur. We make the same hypothesis for reverse spillover, expecting that they may occur even in low-tech clusters.

Our findings for Poland give support to the hypothesis of positive reverse spillovers in both high-tech and low-tech cluster, with results significant (1\%) and positive. Moreover, in the low-tech cluster case the $R \& D$ variable is significant $(1 \%)$ and positive. Not significant or negative results are found for the case of direct spillovers. This is in line with previous findings in the literature. Examining the case of non-clustered firm, we find negative and significant results for reverse spillovers in the case of high-tech sectors. These results confirm our initial hypothesis - spillover may be more likely in the cluster case. In the case of low-tech sectors, the

\footnotetext{
${ }^{14}$ OLS technique is unbiased and consistent only when the explanatory variables are exogenous which is not the case because we have also lagged dependent variables (besides input variables).
} 
result is not significant. Direct spillovers both low-tech and high-tech sectors are not significant. All these results confirm the fact that spillover both reverse and direct are more likely in the case of clusters.

Similarly, for Romania we find significant positive results for reverse spillovers in hightech and low-tech clusters with the importance of the level of R\&D confirmed for the high-tech positive and significant. Results for direct spillovers resemble the Polish ones, i.e. not significant (high-tech) or negative (low-tech). For high-tech non-clustered firms, contrary to Poland, we find significant proof of direct spillovers with a strong role of R\&D and significant negative result for reverse spillovers with no significance of the R\&D coefficient.

\subsection{Levinsohn and Petrin results}

We then estimate a more complex model taking into consideration the effect of some technology gap variables that we expect to give a clearer picture of the way the spillover effects emerge. Always considering the results relative to the second step of the econometric estimation of the model, we may note some interesting results. In this case the variable of greater interest is the one describing the interaction between the spillover and R\&D. It measures the effect of a higher level of R\&D value on the spillover variables. We make the same assumptions on the behavior of the spillover variable as for the benchmark model.

For the case of clusters in Poland, as expected we find significant negative reverse spillovers for the high-tech sectors and positive reverse spillovers for the low-tech sectors. We also find positive direct spillovers both for the high-tech and low-tech sectors. The role of the R\&D gap, on the other hand, is not as important as anticipated which means that the distance from the average $R \& D$ is not essential in the ability to appropriate spillovers, both for domestic and foreign firms. Another interesting finding is that all variables which contain an interaction between the TFP and the spillover variable are significant even though not always with the same sign. In the case of the TFP gap between firms it means that the higher is the gap, the less possible it is for the foreign firm to capture the spillover effects. On the other side, we should note that the fact of having an advantage on the local firms and on the firms of the cluster in general, influences positively the possibility of the spillover effect. We further see that the variables measuring the interaction of the TFP with the R\&D variables are all not significant. This leads to the conclusion that it is more important to have higher productivity than a higher $\mathrm{R} \& \mathrm{D}$ level in order to benefit from spillovers.

For the case of firms not part of clusters, we still find proof for both direct and reverse spillovers, which can be explained with the fact that in this category we have a much larger group 
of firms geographically dispersed but which can still benefit from sectoral spillovers exchange on a country level. In the case of both direct and reverse spillovers for high-tech sectors, the effect is positive, proving the fact that domestic firms are more endowed with absorptive capacities and are also potential source of spillovers for foreign firms. There is a positive reverse spillover effect in the case of low-tech sectors, while it is absent in the case of direct spillover. A possible explanation may be that the $\mathrm{R} \& \mathrm{D}$ gap between foreign and domestic firms is too large and significant to allow for effective transfer of knowledge or technology to the local firms. This could give support to our prediction that belonging to a cluster could positively influence the ability to benefit from spillovers even in circumstances where the R\&D gap is very large. In fact, for the case of low-tech cluster, we have positive significant results for direct spillovers.

In Romania we note that a positive reverse spillover effect is present, contrary to Poland, only in the case of high-tech clusters. Results for direct spillovers are not significant in all cases. This can be easily explained with the fact that Romania has started receiving higher levels of FDI only in recent years and the spillover effect may take some time to occur. Moreover, we do not distinguish for spillover channels or percentage of foreign ownership which could also influence the spillover effects.

We have, thus, found that in clusters we can observe both direct and reverse spillovers, even in low-tech sectors. This confirms our initial hypothesis with regards to the role of the cluster effect for facilitating spillovers not necessarily only in one direction among domestic and foreign firms. For non-clusters we have ambiguous results which is acceptable as the non-cluster group is rather large and is affected by various other factors on national or sectoral level which are not accounted for in our estimations. The interaction between the R\&D of each single firm and the regional $\mathrm{R} \& \mathrm{D}$ is almost never significant which could imply that investment in $\mathrm{R} \& \mathrm{D}$ on the regional level does not necessarily have an impact on the productivity and absorptive capacity of firms as expected.

\subsection{System GMM results}

Analyzing the estimation carried out with the dynamic GMM approach, we find that in the case of Poland the reverse spillover variable for high-tech clusters is positive but the coefficient is not significant. This indicates that the R\&D variable is not significant in helping firms capture benefits from FDI. This could be possible as in the case of reverse spillover, the MNEs are searching for advantages, which are not necessarily based on search for higher technology (especially so for transition or developing countries) but may be embodied by other assets, local knowledge, local labor market expertise, etc. Looking at the coefficient relative to 
the $\mathrm{R} \& \mathrm{D}$ gap we find that it is significant and has the expected negative sign. Similar results are found for direct spillovers where we have a negative result but no statistical significance, while the R\&D gap variable has a positive sign and is significant. Thus, the hypothesis of higher spillover effect in clusters is not confirmed with this method of estimation. The results for the various measures of the TFP gap variable are all significant at the 1\% level for the reverse spillover case. This could indicate that it is possible to take advantage of the spillover effect when the TFP gap is not too big. As in the case of first differenced estimation, the variables including the regional R\&D level are not significant even tough positive.

Considering the case of low-tech sectors, the reverse spillover hypothesis is not confirmed and there are some problems of collinearity. However, the case of direct spillovers is confirmed as in the previous case, because the sign of the coefficient is positive and significant and all the other variables have the expected signs.

In the case of high-tech non-clustered firms, the results relative to the reverse spillover effect are positive and significant. In this particular case, the TFP gap variables are not significant. In the case of the direct effect the spillover effect is significant but only at $10 \%$ level, indicating that in the non-cluster case the $R \& D$ variable is not so important for capturing spillovers. However, all other variables in which the spillover effect is considered have the expected coefficient and sign. For low-tech non-clustered firms, there is no significant results for the reverse spillover effects. These results are not confirmed by those obtained with the first differenced estimation. However, in the case of direct spillovers, all variables are strongly significant $(1 \%)$ and there is a positive proof for both reverse spillovers ( significant at $1 \%$ ) and direct spillovers $(1 \%)$. These results confirm the hypothesis that there may be reverse spillover even in low-tech sectors, and both in cluster and non-clusters.

Considering Romanian high-tech clusters, we have evidence of positive reverse spillover and negative direct spillovers. This presents an interesting case for the assumption that there is a higher possibility of asset-seeking for foreign firms in clusters. In fact, for high-tech nonclustered firms we have negative but not significant results for reverse spillovers. At the same time the ability of domestic firms to benefit from the presence of foreign firms, especially in the high-tech sector could be limited by limited absorptive capacity.

In the case of low-tech clusters, there are no significant results for the direct spillover effect and the instruments are rejected with an evidence of the first order and second order serial correlation. There is a proof for reverse spillover effect (significant at 10\%) but we should consider that also in this case the instruments are rejected. 


\section{ConClusions}

According to the literature on spillovers, the spillover effect should run only in one direction, from foreign to domestic firms. This is the standard model tested in empirical specifications. Usually, the model is made more complex by taking into consideration the fact that there may be some conditionalities such as absorptive capacities or technology gap that may favor the process. However, the mixed results found in the literature suggest that some factors are not properly taken into consideration. First of all, the absorptive capacity may be enhanced by the fact that firms are clustered together. This is why we have investigated whether the spillover effect could be greater by using a dataset properly divided according to a cluster classification. Positive results found both for Romania and Poland confirm our initial hypothesis. Moreover, due to the higher attractiveness of Eastern European countries for FDI, we tried to test whether a reverse spillover hypothesis could be true in this case. Previous studies have been done for mostly for developed countries, but not for transition countries.

Going back to our initial hypotheses, we have find that clusters could have some role in stimulating direct spillovers. We have positive evidence in Poland while none or negative in Romania for both low-tech and high-tech sectors. There is almost no evidence for direct spillovers in non-clusters, with the exception of Polish high-tech clusters. This partially confirms our hypothesis that clusters could have a role in stimulating the absorptive capacity of their participating firms and consequently benefiting from direct spillovers. We can also suggest that the level of economic development could also play a role in the possibility of fully benefiting from such cluster effect. In fact, Poland seems to be a proof of the existence of such effect while Romania offers mixed implications.

We have robust evidence of reverse spillovers in non-clustered firms in Poland while in Romania results are not significant. Polish low-tech clustered are also a source of reverse spillovers while evidence for Romania is not significant but still positive. Positive effects are witnessed for Romanian high-tech clusters while we have proof for negative reverse spillovers in Poland. The role of clusters for reverse spillovers is ambiguous but an interesting fact is that we find reverse spillovers in low-tech sectors which suggests that foreign firms can have assetseeking motivations which are not necessarily targeted to the appropriation of some sort of higher technology.

Our findings could have important implications for FDI and cluster policies. FDI have often been involved in building cluster policies. In fact, where foreign firms are located in clusters, it is likely that their productivity is greater and thus, they are likely to be more willing to collaborate with other local firms and organizations to support the cluster as they could benefit 
from such collaboration themselves. This suggests that clusters could be considered attractive for FDI as foreign firms could be able to benefit from cluster-specific assets and as such the cluster could become a motivation for asset-seeking FDI. On the other hand, domestic firms could be more capable of absorbing direct spillovers if situated in clusters, even in conditions of significantly lower R\&D investments. The evidence from Poland and Romania shows that R\&D level does not seem to be essential for the ability of benefiting from spillovers, while a much more important role is played by productivity. Cluster and FDI policies respectively should be perceived as mutually reinforcing in their design and allowing for these to exploit and create synergies between the ownership advantages of the MNE and the competitive advantage of the location.

Our results are especially important for countries which are less developed economically as they suggest that clusters, and not necessarily technological superiority, could be a source of reverse spillover for foreign firms. In fact, current literature focuses mostly on the possibility of reverse spillovers among developed countries and in technologically advanced sectors. Our results suggest that this is also possible in low-tech sectors and in less developed countries.

\section{REFERENCES}

Arellano, M. and S. Bond (1991). "Some tests of specification for panel data: Monte Carlo evidence and an application to employment equations." Review of Economic Studies. 58: 277297.

Arellano, M. and O.Bover (1995). "Another look at the instrumental-variable estimation of error-components models.” Journal of Econometrics. 68: 29-51.

Aitken, B. and A. Harrison (1999). "Do Domestic Firms Benefit from Direct Foreign Investment? Evidence from Venezuela." American Economic Review. 89(3): 605-618.

Baniak, A. et al. (2005) "On determinants of foreign direct investment in transition economies." Problems of Economic Transition. 48 (2): 6-28.

Belussi, F. (2006) "In search of a theory of spatial clustering: agglomeration vs active clustering." in Asheim,B., P. Cooke and R. Martin, (eds.). Clusters in Regional Development: Critical Reflections and Explorations. Routledge: London

Bevan, A., S.Estrin and K.Meyer (2004).’'Foreign investment location and institutional development in transition economies." International Business Review. 13 (1): 43-64.

Bevan, A. and S.Estrin (2000). "The Determinants of Foreign Direct Investment in Transition Economies.” William Davidson Institute Working Paper No. 342. 
Blalock, G. and Gertler, P. (2004) "Learning from exporting revisited in a less developed setting" Journal of Development Economics. 75 (2):397-416.

Blundell, R. and S. Bond (1999). "GMM Estimation with Persistent Panel Data: An Application to Production Functions," Working Paper W99/04, Institute for Fiscal Studies, London.

Boros-Torstila, J. (1999) “The Determinants of Foreign Direct Investment Operations of Finnish MNCs in Transition Economies, 1990-1995." Helsinki: ETLA, The Research Institute of Finnish Economy, A 28 Series.

Brown, P. and J. Bell (2001) "Industrial Clusters and Small Firm Internationalisation", in J. Taggart, S. Young and N.Hood (eds.). The Multinational in the Millennium: Companies and Countries, Changes and Choices. Houndsmill, Palgrave.

Castellani, D. and A. Zanfei (2007). "Multinational companies and productivity spillovers: is there a specification error?” Applied Economic Letters. (14): 1047-1051.

Damijan, J. et al. (2003). “Technology transfer through FDI in top-10 transition countries: how important are direct effects, horizontal and vertical spillovers?" William Davidson Working Paper Number 549.

Djankov, S. and B. Hoekman(1998). "Foreign Investment and productivity growth in Czech Enterprises.” World Bank Economic Review, World Bank

Driffield, N. (2006). "On the search for spillovers from foreign direct investment with spatial dependency.” Regional Studies. 40 (1): 107-119.

Driffield, N., \& Love, J. H. (2003). "Foreign direct investment, technology sourcing and reverse spillovers.” Manchester School, 71/6, 659-672.

De Propis, L. and N. Driffield (2006). "The importance of clusters for spillovers from foreign direct investment and technology sourcing." Cambridge Journal of Economics, 30:277-291.

Driffield, N. and J.H. Love. (2007) "Linking FDI Motivation and Host Economy Productivity Effects: Conceptual and Empirical Analysis." Journal of International Business Studies. 38(3): 460-73.

Dunning, J. (1998). "Location and the multinational enterprises: a neglected factor?” Journal of International Business Studies. 29:45-66.

Dunning, J.H. (1993) Multinational Enterprises and the Global Economy. Wokingham, England: Addison-Wesley.

Dunning, J. H. (1977) “Trade, Location of Economy Activity and MNE: A Search for an Eclectic Approach.” In Ohlin, P., O. Hesselborn, and P. S. Wijkmaneds. The International Allocation of Economic Activity. London: Macmillan 
Fosfuri A. and M. Motta (1999). "Multinational without advantages". Scandinavian Journal of Economics. 101(4): 617-630.

Girma, S. and K. Wakelin. (2007) "Local Productivity Spillovers from Foreign Direct Investment in the U.K. Electronics Industry." Regional Science and Urban Economics 37(3):399-412.

Görg, H., \& E.Strobl. (2001). "Multinational companies and productivity spillovers: a meta-analysis." Economic Journal (111): 723-739.

Görg, H. and D. Greenaway (2004). "Much Ado about Nothing? Do Domestic Firms Really Benefit from Foreign Direct Investment?” World Bank Research Observer. 19(2):171-97.

Gugler, P. and S.Brunner (2007) "FDI effects on national competitiveness: a cluster approach". International Advances in Economic Research. 13: 268-284.

Habuda, J. and A.Szalavetz (2000). “Technology Transfer, Innovation and Modernisation. The Example of German-owned Hungarian Engineering Firms”. Weltforum Verlag.

Hatzichronoglou, T. (1997). "Revision of the High-Technology Sector and Product Classification.” STI Working Paper 1997/2, OECD, Paris.

He, C. (2002). "Information costs, agglomeration economies and location of foreign direct investment in China." Regional Studies. 36 (9): 1029-1036.

Head, K., J. Ries and D.Swenson (1995). "Agglomeration benefits and location choice: Evidence from Japanese manufacturing investments in the United States." Journal of International Economics. 38(3-4): 223-247.

Javorcik, B.S. and M. Spatareanu (2008). "To share or not to share: does local participation matter for spillovers from foreign direct investment?" Journal of Development Economics. 85: 194-217.

Javorcik, B. S. (2004). "Does Foreign Direct Investment Increase the Productivity of Domestic Firms? In Search of Spillovers Through Backward Linkages." American Economic Review. 94(3): 605-627.

Javorcik, B. S. (2002), "Does Foreign Direct Investment Increase the Productivity of Domestic Firms? In Search of Spillovers through Backward Linkages.” World Bank Policy Research Working Paper 2923.

Jensen C. (2004) "Localized spillovers in the Polish food industry: the role of FDI in the development process.” Regional Studies. 38: 535-550.

Kinoshita, Y. and N. Campos (2003). "Why does FDI go where it goes? New evidence from the transition economies". William Davidson Institute Working Paper No. 573. 
Kogut, Bruce, and Sea J. Chang. 1991. "Technological Capabilities and Japanese Foreign Direct Investment in the United States." Review of Economics and Statistics. 73(3):401-13.

Kornai, J. (1992). "The Post-socialist Transition and the State: Reflections in the Light of Hungarian Fiscal Problems," American Economic Review. 82(2): 1-21.

Konings J. (2001), "The effect of direct foreign investment on domestic firms: evidence from firm level panel data in emerging economies." Economics of Transition. 9(3).

Lankes, H. and A. Venables (1996). "Foreign Direct Investment in Economic Transition: The Changing Pattern of Investments." The Economics of Transition, 4(2): 331-347.

Levinsohn, J. and A. Petrin (2003), "Estimating production functions using inputs to control for unobservables." Review of Economic Studies. 70: 317-334.

Le Bas, C. and C. Sierra (2002). "Location versus Home Country Advantages in R\&D Activities: Some Further Results on Multinationals' Location Strategies.” Research Policy. 31(4): 589-609.

Merlevede, B. and K. Schoors (2005).“Conditional Spillovers from FDI Within and Between Sectors: Evidence from Romania” Department of Economics and CERISE, University of Ghent.

Neven, D. and G. Siotis (1996). "Technology sourcing and FDI in the EC: An empirical evaluation." International Journal of Industrial Organization. 14(5): 543-560.

Nicolini, M. and L.Resmini (2007). "Productivity Spillovers and Multinational Enterprises: In Search of a Spatial Dimension.” DYNREG Working Paper 10. Economic and Social Research Institute, Dublin.

Niosi, J. (1999). "Fourth-Generation R\&D: From Linear Models to Flexible Innovation." Journal of Business Research. 45(2): 111-117.

OECD (1994). Assessing Investment Opportunities in Economies in Transition. Paris, France: OECD.

Porter, M. E. (1998). On competition. Boston MA: Harvard Business School.

Porter, M. (1990). The Competitive Advantage of Nations. The Free Press, New York.

Poznanski, K. (2001). "Building Capitalism with the Communist Tools: Defective Transition in Eastern Europe." East European Politics and Societies, 15 (2): 317-352.

Resmini L. (2000) “The determinants of Foreign direct investment in the CEECs. New evidence from sectoral patterns.” Economics of Transition, 8 (3): 665-689.

Schoors, K. and B. van der Tol (2002). "Foreign Direct Investment Spillovers within and between Sectors: Evidence from Hungarian Data." Working Paper 157. Department of Economics, Ghent University, Belgium. 
Siotis, G. (1999). “Foreign Direct Investment Strategies and Firms' Capabilities.” Journal of Economics and Management Strategy., 8(2):251-70.

Smeets, R. (2008). "Collecting the pieces of the FDI knowledge spillovers puzzle." The World Bank Research Observer. 23(2):107-138.

Smith, D. and R. Florida (1994). "Agglomeration and industrial location: an econometric analysis of Japanese-affiliated manufacturing establishments in automotive-related industries." Journal of Urban Economies. 36:23-41.

Wei, Y. et al. (2008)." Mutual productivity spillovers between foreign and local firms in China." Cambridge Journal of Economics. 32(4):609-631.

Wheeler, D. e A Mody (1992), "International Investment Location Decisions. The Case of US Firms". Journal of International Economics. 33: 57-76.

Woodward, D. et al. (1997). "Taxation and the Location of Foreign Direct Investment in Central Europe.” University of Southern Carolina Working Paper.

Yudaeva, K., Kozlov, K., Melentieva N., and Ponomareva, N. (2003), "Does Foreign Ownership Matter? Russian Experience.” Economics of Transition. 11 (3): 383-410. 
Table 4.

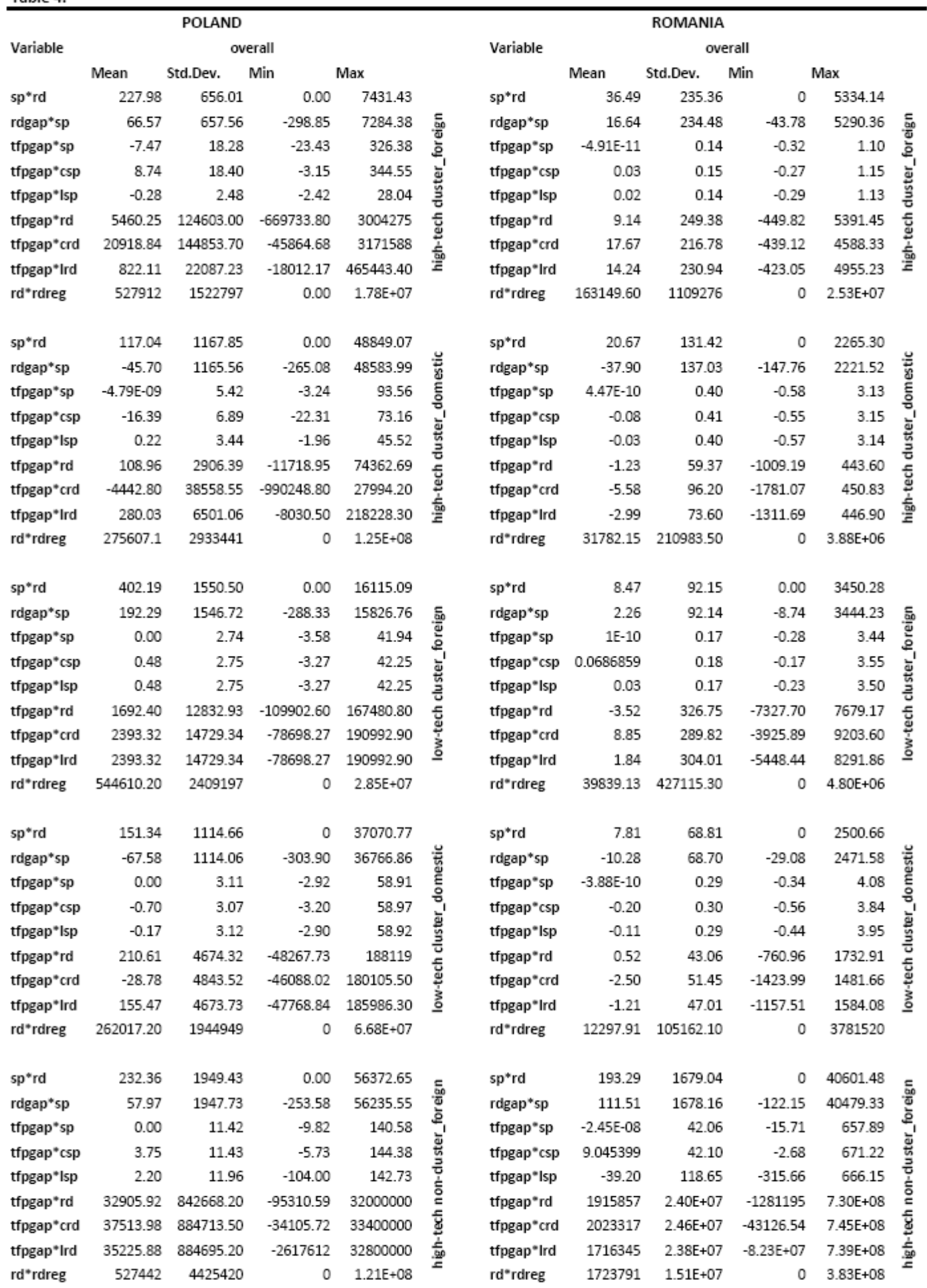




\begin{tabular}{|c|c|c|c|c|c|c|c|c|c|c|}
\hline$s p^{*}$ rd & 213.97 & 1623.82 & 0.00 & 64555.02 & \multirow{9}{*}{ 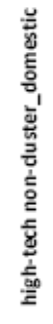 } & \multirow{2}{*}{$\begin{array}{l}\text { sp*rd }^{*} \\
\text { rdgap*sp }\end{array}$} & \multirow{2}{*}{$\begin{array}{r}67.09 \\
-448.61\end{array}$} & \multirow{2}{*}{$\begin{array}{l}573.23 \\
596.99\end{array}$} & \multirow{2}{*}{$\begin{array}{r}0 \\
-870.88\end{array}$} & \multirow{2}{*}{$\begin{array}{l}12344.75 \\
11797.51\end{array}$} \\
\hline rdgap*sp & -62.13 & 1624.42 & -406.64 & 64180.23 & & & & & & \\
\hline tfpgap*sp & 0.00 & 6.30 & -8.53 & 100.72 & & tfpgap*sp & 0.00 & 25.08 & -18.52 & 360.82 \\
\hline tfpgap*csp & -2.44 & 5.15 & -16.60 & 94.55 & & tfpgap"csp & -59.24 & 32.12 & -121.71 & 308.33 \\
\hline tfpgap*Isp & -1.72 & 6.94 & -38.74 & 98.07 & & tfpgap*Isp & -255.60 & 566.97 & -1619.92 & 340.11 \\
\hline tfpgap ${ }^{*}$ rd & 3235.56 & 54023.36 & -97666.27 & 2462456 & & tfpgap"rd & 3927.58 & 52091.17 & -68234.71 & 1496496 \\
\hline tfpgap*crd & 459.65 & 30918.04 & -266208.10 & 2205534 & & tfpgap"crd & -1441.01 & 32301.70 & -438935.50 & 602705.80 \\
\hline tfpgap*Ird & 1974.21 & 46227.76 & -164585.30 & 2350892 & & tfpgap*Ird & -21442.94 & 502804.1 & $-1.89 \mathrm{E}+07$ & 1733591 \\
\hline rd*rdreg & 307460.60 & 2309755 & 0 & $9.02 E+07$ & & rd'rdreg & 93867.86 & 805938.5 & 0 & $1.72 \mathrm{E}+07$ \\
\hline$s p^{*} \mathrm{rd}$ & 160.12 & 628.67 & 0 & 8581.96 & & & & & & \\
\hline rdgap $^{*} s p$ & 38.99 & 628.70 & -164.78 & 8417.18 & 嵒 & & & & & \\
\hline tfpgap*sp & 0.00 & 3.52 & -4.41 & 43.12 & $\frac{2}{2}$ & & & & & \\
\hline tfpgap*csp & 1.31 & 3.53 & -3.25 & 44.73 & $\stackrel{\sharp}{=}$ & & & & & \\
\hline tfpgap*Isp & 0.78 & 3.52 & -3.72 & 44.04 & & & & & & \\
\hline tfpgap ${ }^{*}$ rd & 3819.12 & 29647.62 & -50947.27 & 428856.70 & $=$ & & & & & \\
\hline tfpgap*crd & 5528.98 & 35833.03 & -23274.09 & 473825.30 & $\overline{\mathrm{g}}$ & & & & & \\
\hline tfpgap*Ird & 4842.93 & 33292.49 & -35075.02 & 446924.70 & 호 & & & & & \\
\hline rd"rdreg & 358849.20 & 1426955 & 0 & $2.17 \mathrm{E}+07$ & & & & & & \\
\hline$s p^{*} \mathrm{rd}$ & 159.26 & 911.76 & 0 & 19424.96 & $\breve{U}$ & & & & & \\
\hline rdgap*sp & -34.08 & 909.48 & -298.66 & 19126.29 & $E$ & & & & & \\
\hline tfpgap*sp & 0.00 & 4.09 & -5.17 & 55.36 & 윰 & & & & & \\
\hline tfpgap*csp & -2.06 & 4.14 & -7.93 & 53.62 & 屯 & & & & & \\
\hline tfpgap*Isp & -0.82 & 4.10 & -6.03 & 54.65 & 큰 & & & & & \\
\hline tfpgap*rd & 1367.36 & 21019.31 & -178385.60 & 464774.70 & $=$ & & & & & \\
\hline tfpgap*crd & 561.14 & 19107 & -323231.50 & 412735.20 & f & & & & & \\
\hline tfpgap*Ird & 1052.16 & 20058.79 & -234095.60 & 445661 & s. & & & & & \\
\hline rd'rdreg & 228149.90 & 1305082 & 0 & $2.71 E+07$ & & & & & & \\
\hline
\end{tabular}


Benchmark model

\begin{tabular}{|c|c|c|c|c|c|}
\hline \multicolumn{3}{|c|}{ Poland high-tech clustered firms } & \multicolumn{3}{|c|}{ Poland low-tech clustered firms } \\
\hline & $\begin{array}{l}\text { Reverse } \\
\text { spillovers }\end{array}$ & $\begin{array}{c}\text { Direct } \\
\text { spillovers }\end{array}$ & & $\begin{array}{l}\text { Reverse } \\
\text { spillovers }\end{array}$ & $\begin{array}{c}\text { Direct } \\
\text { spillovers }\end{array}$ \\
\hline $\begin{array}{l}\text { Dependent } \\
\text { variable }\end{array}$ & $\Delta \log$ TFP & $\Delta \log$ TFP & $\begin{array}{l}\text { Dependent } \\
\text { variable }\end{array}$ & $\Delta \log$ TFP & $\Delta \log$ TFP \\
\hline $\begin{array}{l}\text { Estimation } \\
\text { method }\end{array}$ & $\begin{array}{l}\text { Levinsohn } \\
\text { and Petrin }\end{array}$ & $\begin{array}{l}\text { Levinsohn } \\
\text { and Petrin }\end{array}$ & $\begin{array}{l}\text { Estimation } \\
\text { method }\end{array}$ & $\begin{array}{l}\text { Levinsohn } \\
\text { and Petrin }\end{array}$ & $\begin{array}{l}\text { Levinsohn } \\
\text { and Petrin }\end{array}$ \\
\hline dsp & $\begin{array}{l}1.177742^{* * *} \\
(0.3650867)\end{array}$ & $\begin{array}{r}-0.4693291 \\
(0.3659960)\end{array}$ & dsp & $\begin{array}{l}1.244135^{\text {**** }} \\
(0.2432026)\end{array}$ & $\begin{array}{r}-1.127163^{* * * *} \\
(0.1847780)\end{array}$ \\
\hline drd & $\begin{array}{r}0.0000421^{\text {**** }} \\
(0.0000078)\end{array}$ & $\begin{array}{r}0.0000228^{* * *} \\
(0.0000020)\end{array}$ & drd & $\begin{array}{r}0.0000030 \\
(0.0000030)\end{array}$ & $\begin{array}{r}-0.0000102 \\
(0.0000125)\end{array}$ \\
\hline No obs & 672 & 838 & No obs & 659 & 1874 \\
\hline No firms & 244 & 424 & No firms & 261 & 829 \\
\hline$R-s q$ & 0.0289 & 0.0044 & R-sq & 0.0242 & 0.0172 \\
\hline
\end{tabular}

\begin{tabular}{lrr}
\multicolumn{3}{l}{ Poland high-tech non-clustered firms } \\
\hline & $\begin{array}{c}\text { Reverse } \\
\text { spillovers }\end{array}$ & $\begin{array}{c}\text { Direct } \\
\text { spillovers }\end{array}$ \\
\hline $\begin{array}{l}\text { Dependent } \\
\text { variable }\end{array}$ & \multicolumn{1}{c}{$\Delta$ log TFP } & \multicolumn{1}{c}{$\Delta$ log TFP } \\
\hline $\begin{array}{l}\text { Estimation } \\
\text { method }\end{array}$ & $\begin{array}{r}\text { Levinsohn } \\
\text { and Petrin }\end{array}$ & $\begin{array}{r}\text { Levinsohn } \\
\text { and Petrin }\end{array}$ \\
\hline dsp & $-1.049584^{* * *}$ & 0.288288 \\
& $(0.3924186)$ & $(0.3437031)$ \\
drd & 0.0000023 & $0.0000145^{* *}$ \\
& $(0.0000015)$ & $(0.0000069)$ \\
No obs & 2409 & 2451 \\
No firms & 939 & 1491 \\
R-sq & 0.0038 & 0.0021
\end{tabular}

\begin{tabular}{lrr}
\multicolumn{3}{c}{ Poland low-tech non-clustered firms } \\
\hline \hline & $\begin{array}{c}\text { Reverse } \\
\text { spillovers }\end{array}$ & \multicolumn{1}{c}{$\begin{array}{c}\text { Direct } \\
\text { spillovers }\end{array}$} \\
\hline $\begin{array}{l}\text { Dependent } \\
\text { variable }\end{array}$ & $\Delta$ log TFP & \multicolumn{1}{c}{$\Delta$ log TFP } \\
\hline $\begin{array}{l}\text { Estimation } \\
\text { method }\end{array}$ & Levinsohn & \multicolumn{1}{c}{ Levinsohn } \\
and Petrin & \multicolumn{1}{c}{ and Petrin } \\
\hline dsp & -0.3863536 & -0.6379187 \\
& $(0.5957368)$ & $(0.4648046)$ \\
drd & 0.0000044 & $0.0000154^{* *}$ \\
& $(0.0000065)$ & $(0.0000078)$ \\
No obs & 954 & 1305 \\
No firms & 329 & 648 \\
R-sq & 0.0009 & 0.0053
\end{tabular}

\begin{tabular}{lrr}
\multicolumn{2}{c}{ Romania high-tech clustered firms } \\
\hline \hline & $\begin{array}{c}\text { Reverse } \\
\text { spillovers }\end{array}$ & $\begin{array}{c}\text { Direct } \\
\text { spillovers }\end{array}$ \\
\hline $\begin{array}{l}\text { Dependent } \\
\text { variable }\end{array}$ & \multicolumn{1}{c}{$\Delta$ log TFP } & \multicolumn{1}{c}{$\Delta$ log TFP } \\
\hline $\begin{array}{l}\text { Estimation } \\
\text { method }\end{array}$ & $\begin{array}{r}\text { Levinsohn } \\
\text { and Petrin }\end{array}$ & $\begin{array}{r}\text { Levinsohn } \\
\text { and Petrin }\end{array}$ \\
\hline dsp & $2.68874^{* *}$ & -1.44828 \\
& $(1.3501720)$ & $(0.9317285)$ \\
drd & $0.00000509 * *$ & $-0.00005^{* * *}$ \\
& $(0.0000016)$ & $(0.0000120)$ \\
No obs & 415 & 557 \\
No firms & 90 & 119 \\
R-sq & 0.0122 & 0.0059
\end{tabular}

\begin{tabular}{|c|c|c|}
\hline & $\begin{array}{c}\text { Reverse } \\
\text { spillovers }\end{array}$ & $\begin{array}{c}\text { Direct } \\
\text { spillovers }\end{array}$ \\
\hline $\begin{array}{l}\text { Dependent } \\
\text { variable }\end{array}$ & $\Delta \log$ TFP & $\Delta \log$ TFP \\
\hline $\begin{array}{l}\text { Estimation } \\
\text { method }\end{array}$ & $\begin{array}{l}\text { Levinsohn } \\
\text { and Petrin }\end{array}$ & $\begin{array}{l}\text { Levinsohn } \\
\text { and Petrin }\end{array}$ \\
\hline dsp & $\begin{array}{l}2.593724^{* * *} \\
(0.6351319)\end{array}$ & $\begin{array}{r}-2.974141^{* * *} \\
(0.5913304)\end{array}$ \\
\hline drd & $\begin{array}{r}0.0000033 \\
(0.0000206)\end{array}$ & $\begin{array}{r}-0.0001037^{* *} \\
(0.0000510)\end{array}$ \\
\hline No obs & 2151 & 1754 \\
\hline No firms & 671 & 399 \\
\hline R-sq & 0.0068 & 0.0146 \\
\hline
\end{tabular}


Romania high-tech non-clustered firms

\begin{tabular}{lrr}
\hline \hline & $\begin{array}{c}\text { Reverse } \\
\text { spillovers }\end{array}$ & \multicolumn{1}{c}{$\begin{array}{c}\text { Direct } \\
\text { spillovers }\end{array}$} \\
\hline $\begin{array}{l}\text { Dependent } \\
\text { variable }\end{array}$ & $\Delta$ log TFP & $\Delta$ log TFP \\
\hline $\begin{array}{lrr}\text { Estimation } \\
\text { method }\end{array}$ & $\begin{array}{r}\text { Levinsohn and } \\
\text { Petrin }\end{array}$ & $\begin{array}{r}\text { Levinsohn and } \\
\text { Petrin }\end{array}$ \\
\hline dsp & $-4.977045^{* * *}$ & $3.992738^{* * *}$ \\
& $(0.7834222)$ & $(0.5385206)$ \\
drd & 0.0000010 & $0.0000392^{* * *}$ \\
& $(0.0000007)$ & $(0.0000100)$ \\
No obs & 1306 & 1831 \\
No firms & 201 & 359 \\
R-sq & 0.0298 & 0.0301
\end{tabular}


Table. 5

Poland high-tech clustered firms

\begin{tabular}{|c|c|c|c|c|c|c|}
\hline \multirow[b]{2}{*}{$\begin{array}{l}\text { Dependent } \\
\text { variable }\end{array}$} & \multicolumn{3}{|c|}{ Reverse spillovers } & \multicolumn{3}{|c|}{ Direct spillovers } \\
\hline & log Sales & $\Delta \log$ TFP & log Sales & log Sales & $\Delta \log$ TFP & log Sales \\
\hline $\begin{array}{l}\text { Estimation } \\
\text { method }\end{array}$ & OLS & $\begin{array}{r}\text { Levinsohn and } \\
\text { Petrin }\end{array}$ & GMM & OLS & $\begin{array}{l}\text { Levinsohn } \\
\text { and Petrin }\end{array}$ & GMM \\
\hline Inemp & $\begin{array}{r}0.1645246 * * * \\
(0.0201046)\end{array}$ & & $\begin{array}{r}0.129312^{* * *} \\
(0.0360615)\end{array}$ & $\begin{array}{r}0.1854964^{* * *} \\
(0.0209627)\end{array}$ & & $\begin{array}{r}0.5806591 * * * \\
(0.2217113)\end{array}$ \\
\hline Inmaterial & $\begin{array}{r}0.5452597^{* * * *} \\
(0.0386986)\end{array}$ & & $\begin{array}{r}0.4762065 * * * \\
(0.0658625)\end{array}$ & $\begin{array}{r}0.6101562^{* * *} \\
(0.0227343)\end{array}$ & & $\begin{array}{r}0.6925152^{* * *} \\
(0.0844492)\end{array}$ \\
\hline Incap & $\begin{array}{r}0.0690766 * * * \\
(0.0158622)\end{array}$ & & $\begin{array}{r}0.0599061^{* * *} \\
(0.0218405)\end{array}$ & $\begin{array}{r}0.1093076 * * * \\
(0.0146226)\end{array}$ & & $\begin{array}{r}0.0567806 \\
(0.0796099)\end{array}$ \\
\hline IInsales & & & $\begin{array}{r}0.2191206^{* * *} * \\
(0.0769214)\end{array}$ & & & $\begin{array}{r}0.2014093^{* *} \\
(0.0950923)\end{array}$ \\
\hline sp*rd & $\begin{array}{r}0.0007322 \\
(0.0004787)\end{array}$ & $\begin{array}{r}-0.0011534^{* *} \\
(0.0004552)\end{array}$ & $\begin{array}{r}0.0006227 \\
(0.0005728)\end{array}$ & $\begin{array}{r}0.0000820 \\
(0.0006868)\end{array}$ & $\begin{array}{r}0.0029526 * * * \\
(0.0005230)\end{array}$ & $\begin{array}{r}-0.0023632 \\
(0.0024128)\end{array}$ \\
\hline rdgap*sp & $\begin{array}{r}-0.0003658 \\
(0.0002252)\end{array}$ & $\begin{array}{r}0.0001928 \\
(0.0002249)\end{array}$ & $\begin{array}{r}-0.000485^{* * *} \\
(0.0001771)\end{array}$ & $\begin{array}{r}0.0000910 \\
(0.0002353)\end{array}$ & $\begin{array}{r}0.0017798^{* * *} \\
(0.0003630)\end{array}$ & $\begin{array}{l}0.0005241^{*} \\
(0.0002768)\end{array}$ \\
\hline tfpgap*sp & $\begin{array}{r}0.0249554^{* * * *} \\
(0.0054980)\end{array}$ & $\begin{array}{r}-0.0516039^{* * * *} \\
(0.0075582)\end{array}$ & $\begin{array}{r}0.0302647^{* * *} \\
(0.0051011)\end{array}$ & $\begin{array}{r}0.1737773 * * * \\
(0.0363621)\end{array}$ & $\begin{array}{c}-0.074487^{* *} \\
(0.0372904)\end{array}$ & $\begin{array}{r}0.1599269 * * * \\
(0.0268813)\end{array}$ \\
\hline tfpgaploc*sp & $\begin{array}{r}-0.0092913 \\
(0.0084929)\end{array}$ & $\begin{array}{r}0.071176^{* * *} \\
(0.0083244)\end{array}$ & $\begin{array}{r}0.0204573^{* * *} \\
(0.0069598)\end{array}$ & $\begin{array}{r}0.0172458 * * * \\
(0.0036447)\end{array}$ & $\begin{array}{r}0.0133516 * * * \\
(0.0044080)\end{array}$ & $\begin{array}{r}0.0016651 \\
(0.0049095)\end{array}$ \\
\hline tfpgapcl*sp & $\begin{array}{r}0.1299817^{* * * *} \\
(0.0278920)\end{array}$ & $\begin{array}{r}0.0438364^{* * *} \\
(0.0088170)\end{array}$ & $\begin{array}{r}0.1165514 * * * \\
(0.0211202)\end{array}$ & $\begin{array}{r}0.4019518^{* * *} \\
(0.0652000)\end{array}$ & $\begin{array}{r}0.2782478 * * * \\
(0.0853362)\end{array}$ & $\begin{array}{r}0.4230061 * * * \\
(0.05555362)\end{array}$ \\
\hline tfpgap*rd & $\begin{array}{r}-0.0000005 \\
(0.0000009)\end{array}$ & $\begin{array}{r}0.0000004 \\
(0.0000019)\end{array}$ & $\begin{array}{r}0.0000021 \\
(0.0000017)\end{array}$ & $\begin{array}{r}-0.0000162 \\
(0.0000183)\end{array}$ & $\begin{array}{r}0.0000222 \\
(0.0000234)\end{array}$ & $\begin{array}{r}-0.0000932^{* *} \\
(0.0000453)\end{array}$ \\
\hline tfpgaploc*rd & $\begin{array}{r}-0.0000009 \\
(0.0000008)\end{array}$ & $\begin{array}{r}-0.0000019 \\
(0.0000018)\end{array}$ & $\begin{array}{c}-0.0000029^{*} \\
(0.0000017)\end{array}$ & $\begin{array}{r}0.0000048 \\
(0.0000042)\end{array}$ & $\begin{array}{r}0.0000030 \\
(0.0000048)\end{array}$ & $\begin{array}{r}-0.0000041 \\
(0.0000090)\end{array}$ \\
\hline tfpgapcl*rd & $\begin{array}{r}-0.00000313^{* *} \\
(0.0000015)\end{array}$ & $\begin{array}{r}0.0000061 \\
(0.0000039)\end{array}$ & $\begin{array}{r}0.0000033^{* * *} * \\
(0.0000012)\end{array}$ & $\begin{array}{r}0.0000033 \\
(0.0000104)\end{array}$ & $\begin{array}{r}-0.0000159 \\
(0.0000130)\end{array}$ & $\begin{array}{l}0.0000697 * \\
(0.0000389)\end{array}$ \\
\hline rd*rdregional & $\begin{array}{r}-0.0000001 \\
(0.0000002)\end{array}$ & $\begin{array}{r}0.000000535^{* *} \\
(0.0000002)\end{array}$ & $\begin{array}{r}0.0000001 \\
(0.0000003)\end{array}$ & $\begin{array}{r}0.0000001 \\
(0.0000003)\end{array}$ & $\begin{array}{l}-0.0000004^{*} \\
(1.9100000)\end{array}$ & $\begin{array}{r}0.0000004 \\
(0.0000009)\end{array}$ \\
\hline Year dummies & Yes & Yes & Yes & Yes & Yes & Yes \\
\hline No obs & 898 & 672 & 736 & 1199 & 838 & 954 \\
\hline No firms & 244 & 244 & 244 & 424 & 424 & 424 \\
\hline$R-s q$ & 0.9513 & 0.4147 & & 0.9132 & 0.5580 & \\
\hline Hansen $J$ test & & & 0.05 & & & 0.21 \\
\hline $\begin{array}{l}\text { Arellano-Bond } \\
\text { test for AR (1) }\end{array}$ & & & 0.189 & & & 0.06 \\
\hline $\begin{array}{l}\text { Arellano-Bond } \\
\text { test for AR (2) }\end{array}$ & & & 0.067 & & & 0.622 \\
\hline
\end{tabular}

1) Robust standard errors are in parenthesis.

2) Significance at the $1 \%, 5 \%$, and $10 \%$ levels is denoted by $* * * * *$, and ${ }^{*}$, respectively. 
Table. 6

Poland low-tech clustered firms

\begin{tabular}{|c|c|c|c|c|c|c|}
\hline \multirow[b]{2}{*}{$\begin{array}{l}\text { Dependent } \\
\text { variable }\end{array}$} & \multicolumn{3}{|c|}{ Reverse spillovers } & \multicolumn{3}{|c|}{ Direct spillovers } \\
\hline & log Sales & $\Delta \log$ TFP & log Sales & log Sales & $\Delta \log$ TFP & log Sales \\
\hline $\begin{array}{l}\text { Estimation } \\
\text { method }\end{array}$ & OLS & $\begin{array}{l}\text { Levinsohn } \\
\text { and Petrin }\end{array}$ & GMM & OLS & $\begin{array}{l}\text { Levinsohn } \\
\text { and Petrin }\end{array}$ & GMM \\
\hline Inemp & $\begin{array}{r}0.2061044 * * * \\
(0.0174325)\end{array}$ & & $\begin{array}{r}0.174402^{* * *} \\
(0.0321003)\end{array}$ & $\begin{array}{r}0.1723513 * * * \\
(0.0181500)\end{array}$ & & $\begin{array}{r}0.0618994 \\
(0.0644432)\end{array}$ \\
\hline Inmaterial & $\begin{array}{r}0.4232025 * * * \\
(0.0219281)\end{array}$ & & $\begin{array}{r}0.3417289 * * * \\
(0.0307672)\end{array}$ & $\begin{array}{r}0.4262901^{* * * *} \\
(0.0131099)\end{array}$ & & $\begin{array}{r}0.3396743^{* * *} \\
(0.0397907)\end{array}$ \\
\hline Incap & $\begin{array}{r}0.2568082^{* * * *} \\
(0.0224690)\end{array}$ & & $\begin{array}{r}0.2070185 * * * \\
(0.0383705)\end{array}$ & $\begin{array}{r}0.2268099^{* * *} * \\
(0.0144290)\end{array}$ & & $\begin{array}{r}0.1514643^{* * *} \\
(0.0430226)\end{array}$ \\
\hline IInsales & & & $\begin{array}{r}0.1894906 * * \\
(0.0756733)\end{array}$ & & & $\begin{array}{r}0.4128718 * * * \\
(0.0944784)\end{array}$ \\
\hline sp*rd & $\begin{array}{r}0.0004356 \\
(0.0003591)\end{array}$ & $\begin{array}{r}0.0006205^{* * *} \\
(0.0002033)\end{array}$ & $\begin{array}{r}-0.0000364 \\
(0.0002439)\end{array}$ & $\begin{array}{r}0.0002361 \\
(0.0001506)\end{array}$ & $\begin{array}{r}0.0012058^{* * *} \\
(0.0003238)\end{array}$ & $\begin{array}{r}0.000373^{* * *} \\
(0.0001329)\end{array}$ \\
\hline rdgap*sp & $\begin{array}{r}-0.0002829^{* *} \\
(0.0001356)\end{array}$ & $\begin{array}{r}0.0007567^{* * *} \\
(0.0001220)\end{array}$ & $\begin{array}{r}-0.0002431^{* *} \\
(0.0000981)\end{array}$ & $\begin{array}{r}-0.0006309^{* * *} * \\
(0.0000978)\end{array}$ & $\begin{array}{r}0.0013706^{* * *} \\
(0.0003025)\end{array}$ & $\begin{array}{r}0.0005562^{* * *} \\
(0.0001137)\end{array}$ \\
\hline tfpgap*sp & -- & -- & -- & $\begin{array}{r}0.1886597^{* * *} * \\
(0.0233256)\end{array}$ & $\begin{array}{l}2.475713^{* *} \\
(0.7944700)\end{array}$ & $\begin{array}{r}0.1120256 * * * \\
(0.0293826)\end{array}$ \\
\hline tfpgaploc*sp & $\begin{array}{r}0.1648586 * * * \\
(0.0282413)\end{array}$ & $\begin{array}{r}0.1806908^{* * * *} \\
(0.0204862)\end{array}$ & $\begin{array}{r}0.1729515 * * * \\
(0.0188189)\end{array}$ & $\begin{array}{r}-0.0474385 \\
(0.0295082)\end{array}$ & $\begin{array}{l}0.0150949 * \\
(0.0079499)\end{array}$ & $\begin{array}{r}-0.0216746 \\
(0.0208928)\end{array}$ \\
\hline tfpgapcl*sp & -- & - & -- & - & $\begin{array}{r}-2.391655^{* * *} \\
(0.8092877)\end{array}$ & -- \\
\hline tfpgap*rd & $\begin{array}{r}0.0000162 \\
(0.0000459)\end{array}$ & $\begin{array}{r}-0.0000219 \\
(0.0000232)\end{array}$ & $\begin{array}{r}-0.0000357 \\
(0.0000359)\end{array}$ & $\begin{array}{l}0.0002169 * \\
(0.0001145)\end{array}$ & $\begin{array}{r}0.0000288 \\
(0.0000367)\end{array}$ & $\begin{array}{r}-0.0000686 \\
(0.0000860)\end{array}$ \\
\hline tfpgaploc*rd & $\begin{array}{r}-0.0000173 \\
(0.0000448)\end{array}$ & $\begin{array}{r}0.0000199 \\
(0.0000223)\end{array}$ & $\begin{array}{r}0.0000332 \\
(0.0000350)\end{array}$ & $\begin{array}{l}0.0000593^{*} \\
(0.0000330)\end{array}$ & $\begin{array}{r}-0.0000007 \\
(0.0000131)\end{array}$ & $\begin{array}{r}0.0000057 \\
(0.0000111)\end{array}$ \\
\hline tfpgapcl*rd & - & - & -- & $\begin{array}{c}-0.0002783^{*} \\
(0.0001457)\end{array}$ & $\begin{array}{r}-0.0000382 \\
(0.0000431)\end{array}$ & $\begin{array}{r}0.0000571 \\
(0.0000832)\end{array}$ \\
\hline rd*rdregional & $\begin{array}{r}-0.0000001 \\
(0.0000001)\end{array}$ & $\begin{array}{r}0.0000001 \\
(0.0000001)\end{array}$ & $\begin{array}{r}0.0000001 \\
(0.0000001)\end{array}$ & $\begin{array}{r}0.000000241^{* * *} * \\
(0.0000001)\end{array}$ & $\begin{array}{r}0.0000001 \\
(0.0000001)\end{array}$ & $\begin{array}{l}0.0000001^{*} \\
(0.0000001)\end{array}$ \\
\hline Year dummies & Yes & Yes & Yes & Yes & Yes & Yes \\
\hline No obs & 888 & 659 & 720 & 2582 & 1874 & 2050 \\
\hline No firms & 261 & 261 & 261 & 829 & 829 & 829 \\
\hline$R-s q$ & 0.9535 & 0.6147 & & 0.8715 & 0.4324 & \\
\hline Hansen $J$ test & & & 0.067 & & & 0.567 \\
\hline $\begin{array}{l}\text { Arellano-Bond } \\
\text { test for AR (1) }\end{array}$ & & & 0.408 & & & 0.029 \\
\hline $\begin{array}{l}\text { Arellano-Bond } \\
\text { test for AR (2) }\end{array}$ & & & 0.555 & & & 0.719 \\
\hline
\end{tabular}

1) Robust standard errors are in parenthesis.

2) Significance at the $1 \%, 5 \%$, and $10 \%$ levels is denoted by ***, **, and *, respectively. 
Table. 7

Poland high-tech non-clustered firms

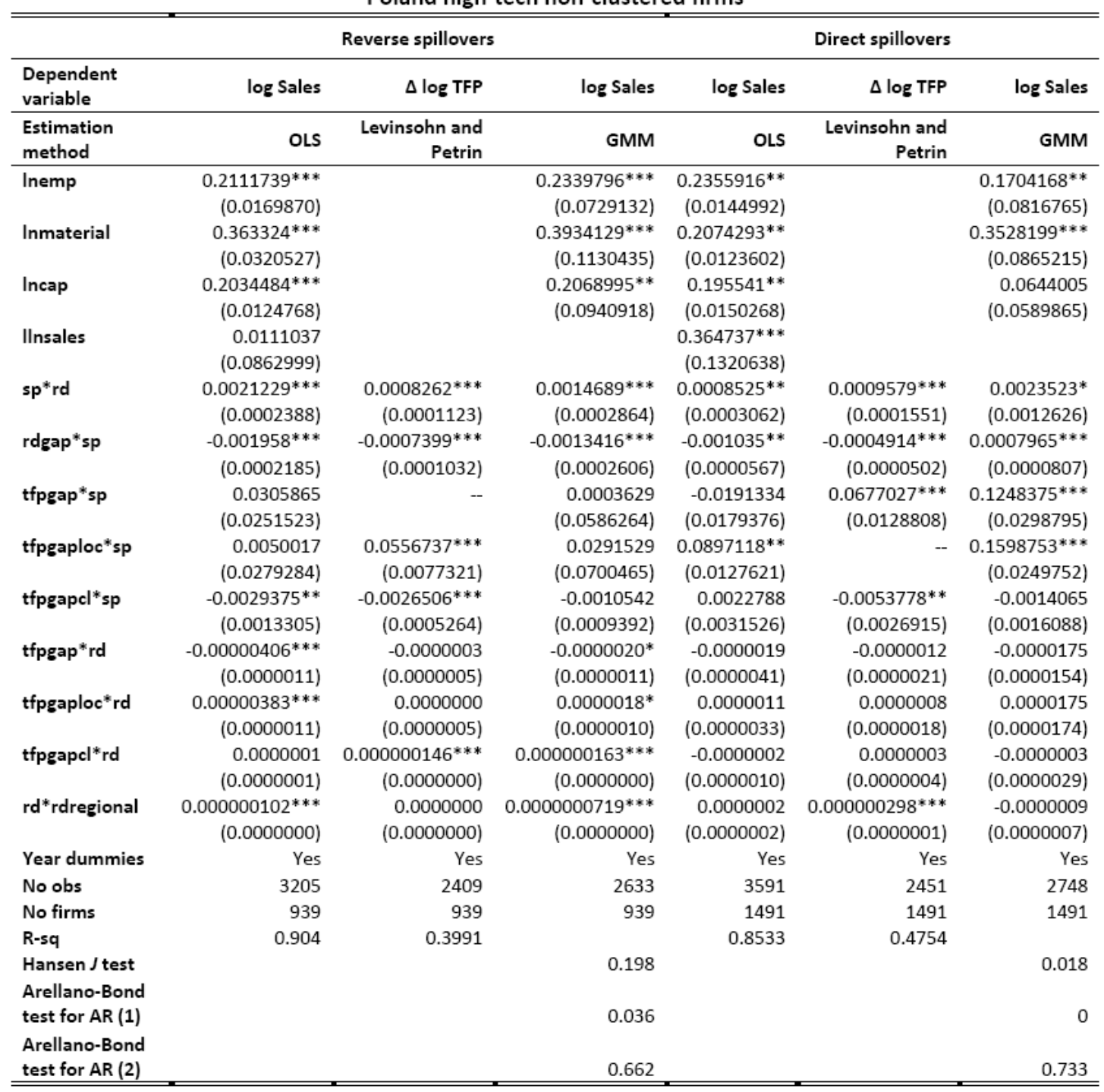

1) Robust standard errors are in parenthesis.

2) Significance at the $1 \%, 5 \%$, and $10 \%$ levels is denoted by ${ }^{* *},{ }^{* *}$, and $*$, respectively. 
Table. 8

Poland low-tech non-clustered firms

\begin{tabular}{|c|c|c|c|c|c|c|}
\hline \multirow[b]{2}{*}{$\begin{array}{l}\text { Dependent } \\
\text { variable }\end{array}$} & \multicolumn{3}{|c|}{ Reverse spillovers } & \multicolumn{3}{|c|}{ Direct spillovers } \\
\hline & log Sales & $\Delta \log$ TFP & log Sales & log Sales & $\Delta \log$ TFP & log Sales \\
\hline $\begin{array}{l}\text { Estimation } \\
\text { method }\end{array}$ & OLS & $\begin{array}{r}\text { Levinsohn and } \\
\text { Petrin }\end{array}$ & GMM & OLS & $\begin{array}{r}\text { Levinsohn and } \\
\text { Petrin }\end{array}$ & GMM \\
\hline Inemp & $\begin{array}{r}0.202669 * * * \\
(0.0175534)\end{array}$ & & $\begin{array}{r}0.1236776 * * \\
(0.0614952)\end{array}$ & $\begin{array}{r}0.2047734^{* * * *} \\
(0.0259322)\end{array}$ & & $\begin{array}{r}0.2175412^{* * *} \\
(0.0622991)\end{array}$ \\
\hline Inmaterial & $\begin{array}{r}0.2735847^{* * *} \\
(0.0165809)\end{array}$ & & $\begin{array}{r}0.3007546 * * * \\
(0.0310032)\end{array}$ & $\begin{array}{r}0.2744222^{* * *} \\
(0.0162588)\end{array}$ & & $\begin{array}{r}0.2171312 * * * \\
(0.0301694)\end{array}$ \\
\hline Incap & $\begin{array}{r}0.2651528 * * * \\
(0.0126129)\end{array}$ & & $\begin{array}{r}0.1321906^{* * *} \\
(0.0315981)\end{array}$ & $\begin{array}{r}0.2579546 * * * \\
(0.0168102)\end{array}$ & & $\begin{array}{r}0.1205229 * * * \\
(0.0416046)\end{array}$ \\
\hline IInsales & & & $\begin{array}{r}0.1525581^{* * *} \\
(0.0544797)\end{array}$ & & & $\begin{array}{r}0.3853884 * * * \\
(0.0757589)\end{array}$ \\
\hline sp*rd & $\begin{array}{r}0.0022483 * * * \\
(0.0004408)\end{array}$ & $\begin{array}{r}0.0010704^{* *} \\
(0.0004222)\end{array}$ & $\begin{array}{r}0.0025393^{* * * *} \\
(0.0004266)\end{array}$ & $\begin{array}{r}0.0018691^{* *} \\
(0.0008416)\end{array}$ & $\begin{array}{r}0.0006931 \\
(0.0006991)\end{array}$ & $\begin{array}{l}0.0014421^{*} \\
(0.0007737)\end{array}$ \\
\hline rdgap*sp & $\begin{array}{r}0.0019202^{* * *} \\
(0.0002201)\end{array}$ & $\begin{array}{r}0.0015517^{* * *} \\
(0.0001492)\end{array}$ & $\begin{array}{r}-0.0015114^{* * *} \\
(0.0002234)\end{array}$ & $\begin{array}{r}-0.001693^{* * *} \\
(0.0001389)\end{array}$ & $\begin{array}{r}-0.001191^{* * *} \\
(0.0001178)\end{array}$ & $\begin{array}{r}0.0015492 * * * \\
(0.0001541)\end{array}$ \\
\hline tfpgap*sp & -- & - & -- & $\begin{array}{r}0.0495126^{* * * *} \\
(0.0233924)\end{array}$ & $\begin{array}{r}0.0777558^{* * *} \\
(0.0082702)\end{array}$ & $\begin{array}{r}0.0873321 * * * \\
(0.0264074)\end{array}$ \\
\hline tfpgaploc*sp & $\begin{array}{r}0.1272139 * * * \\
(0.0160045)\end{array}$ & $\begin{array}{r}0.1361628 * * * \\
(0.0150405)\end{array}$ & $\begin{array}{r}0.1154803 * * * \\
(0.0172539)\end{array}$ & $\begin{array}{r}0.1568117^{* * *} \\
(0.0150072)\end{array}$ & $\begin{array}{r}0.1709179 * * * \\
(0.0215616)\end{array}$ & $\begin{array}{r}0.1489874 * * * \\
(0.0181283)\end{array}$ \\
\hline tfpgapcl*sp & - & - & - & - & - & - \\
\hline tfpgap*rd & $\begin{array}{l}-0.0000677 \\
(0.0000646)\end{array}$ & $\begin{array}{r}0.0000545 \\
(0.0000530)\end{array}$ & $\begin{array}{r}-0.0001495^{* * *} \\
(0.0000521)\end{array}$ & $\begin{array}{r}0.0001169^{* * *} \\
(0.0000444)\end{array}$ & $\begin{array}{r}0.0000725 \\
(0.0000518)\end{array}$ & $\begin{array}{r}0.0000532 \\
(0.0000420)\end{array}$ \\
\hline tfpgaploc*rd & $\begin{array}{r}-0.0000867 \\
(0.0000803)\end{array}$ & $\begin{array}{r}0.0000509 \\
(0.0000630)\end{array}$ & $\begin{array}{r}-0.0001755^{* * *} \\
(0.0000668)\end{array}$ & $\begin{array}{r}0.0000899 * * * \\
(0.0000331)\end{array}$ & $\begin{array}{l}0.0000451^{*} \\
(0.0000244)\end{array}$ & $\begin{array}{r}0.0000270 \\
(0.0000258)\end{array}$ \\
\hline tfpgapcl*rd & $\begin{array}{r}0.0001525 \\
(0.0001443)\end{array}$ & $\begin{array}{r}-0.0001057 \\
(0.0001156)\end{array}$ & $\begin{array}{r}0.0003226 * * * \\
(0.0001184)\end{array}$ & $\begin{array}{r}0.0002074^{* * *} \\
(0.0000730)\end{array}$ & $\begin{array}{r}-0.0001179 \\
(0.0000754)\end{array}$ & $\begin{array}{r}-0.0000809 \\
(0.0000653)\end{array}$ \\
\hline rd*rdregional & $\begin{array}{r}-0.0000001 \\
(0.0000002)\end{array}$ & $\begin{array}{r}0.0000003 \\
(0.0000002)\end{array}$ & $\begin{array}{r}0.000000485^{* * *} \\
(0.0000002)\end{array}$ & $\begin{array}{r}-0.0000001 \\
(0.0000005)\end{array}$ & $\begin{array}{r}0.0000004 \\
(0.0000005)\end{array}$ & $\begin{array}{r}0.0000001 \\
(4.7600000)\end{array}$ \\
\hline Year dummies & Yes & Yes & Yes & Yes & Yes & Yes \\
\hline No obs & 1263 & 954 & 1044 & 1857 & 1305 & 1477 \\
\hline No firms & 329 & 329 & 329 & 648 & 648 & 648 \\
\hline$R-s q$ & 0.9486 & 0.6566 & & 0.8943 & 0.556 & \\
\hline Hansen $J$ test & & & 0.628 & & & 0.213 \\
\hline $\begin{array}{l}\text { Arellano-Bond } \\
\text { test for AR (1) }\end{array}$ & & & 0.106 & & & 0.025 \\
\hline $\begin{array}{l}\text { Arellano-Bond } \\
\text { test for AR (2) }\end{array}$ & & & 0.699 & & & 0.201 \\
\hline
\end{tabular}

1) Robust standard errors are in parenthesis.

2) Significance at the $1 \%, 5 \%$, and $10 \%$ levels is denoted by ${ }^{* * *}, * *$, and *, respectively. 
Table. 9

Romania high-tech clustered firms

\begin{tabular}{|c|c|c|c|c|c|c|}
\hline \multirow[b]{2}{*}{$\begin{array}{l}\text { Dependent } \\
\text { variable }\end{array}$} & \multicolumn{3}{|c|}{ Reverse spillovers } & \multicolumn{3}{|c|}{ Direct spillovers } \\
\hline & log Sales & $\Delta \log$ TFP & log Sales & log Sales & $\Delta \log$ TFP & log Sales \\
\hline $\begin{array}{l}\text { Estimation } \\
\text { method }\end{array}$ & OLS & $\begin{array}{l}\text { Levinsohn } \\
\text { and Petrin }\end{array}$ & GMM & OLS & $\begin{array}{l}\text { Levinsohn } \\
\text { and Petrin }\end{array}$ & GMM \\
\hline Inemp & $\begin{array}{r}0.2231887^{* * *} \\
(0.0117396)\end{array}$ & & $\begin{array}{r}0.2143848 * * * \\
(0.0305506)\end{array}$ & $\begin{array}{r}0.1754862^{* * * *} \\
(0.0080252)\end{array}$ & & $\begin{array}{r}0.1692237 * * * \\
(0.0293311)\end{array}$ \\
\hline Inmaterial & $\begin{array}{r}0.7798415^{* * *} \\
(0.0165629)\end{array}$ & & $\begin{array}{r}0.7712303^{* * *} \\
(0.0231514)\end{array}$ & $\begin{array}{r}0.7899465 * * * \\
(0.0087987)\end{array}$ & & $\begin{array}{r}0.6937577^{* * *} \\
(0.0413997)\end{array}$ \\
\hline Incap & $\begin{array}{r}0.0066129 \\
(0.0164328)\end{array}$ & & $\begin{array}{r}0.0167750 \\
(0.0207463)\end{array}$ & $\begin{array}{r}0.0009811 \\
(0.0088175)\end{array}$ & & $\begin{array}{r}-0.0873862^{* *} \\
(0.0405373)\end{array}$ \\
\hline Ilnsales & & & $\begin{array}{r}0.026237 \\
0.0254159\end{array}$ & & & $\begin{array}{r}0.2044818^{* * * *} \\
(0.0596323)\end{array}$ \\
\hline sp*rd & $\begin{array}{r}0.0070249 * * * \\
(0.0022359)\end{array}$ & $\begin{array}{r}0.0047204^{* * *} \\
(0.0014471)\end{array}$ & $\begin{array}{r}0.005846^{* * *} \\
(0.0015024)\end{array}$ & $\begin{array}{r}-0.0094119^{*} \\
(0.0054149)\end{array}$ & $\begin{array}{r}-0.0024306 \\
(0.0026800)\end{array}$ & $\begin{array}{r}-0.0273809^{* * *} \\
(0.0090604)\end{array}$ \\
\hline rdgap*sp & $\begin{array}{r}-0.0034575^{* * *} \\
(0.0011304)\end{array}$ & $\begin{array}{r}-0.0043293^{* * *} \\
(0.0009537)\end{array}$ & $\begin{array}{r}0.0046832^{* * *} \\
(0.0004669)\end{array}$ & $\begin{array}{r}0.0004855^{* * *} \\
(0.0001455)\end{array}$ & $\begin{array}{r}-0.001071 * * * \\
(0.0002277)\end{array}$ & $\begin{array}{r}-0.0008681^{* * *} \\
(0.0002843)\end{array}$ \\
\hline tfpgap*sp & - & - & -- & - & $\begin{array}{r}0.6831687^{* * *} \\
(0.0849061)\end{array}$ & - \\
\hline tfpgaploc*sp & -- & - & -- & $\begin{array}{r}0.8707392^{* * *} \\
(0.0627861)\end{array}$ & -- & $\begin{array}{r}\left(0.7127022^{* * *}\right) \\
(0.1088462)\end{array}$ \\
\hline tfpgapel*sp & $\begin{array}{r}2.723817^{* * *} \\
(0.2817541)\end{array}$ & $\begin{array}{r}2.265972 * * * \\
(0.3859955)\end{array}$ & $\begin{array}{r}2.585335 * * * \\
(0.2635977)\end{array}$ & - & - & - \\
\hline tfpgap*rd & $\begin{array}{r}0.0022638 \\
(0.0025610)\end{array}$ & $\begin{array}{r}0.0007287 \\
(0.0029822)\end{array}$ & $\begin{array}{r}0.0024020 \\
(0.0024568)\end{array}$ & $\begin{array}{r}0.0630214 \\
(0.0386853)\end{array}$ & $\begin{array}{r}0.0256275 \\
(0.0202233)\end{array}$ & $\begin{array}{r}0.1947275 * * * * \\
(0.0632205)\end{array}$ \\
\hline tfpgaploc*rd & $\begin{array}{r}0.0022720 \\
(0.0032129)\end{array}$ & $\begin{array}{r}0.0011362 \\
(0.0036936)\end{array}$ & $\begin{array}{r}0.0029381 \\
(0.0032038)\end{array}$ & $\begin{array}{r}0.0528593 \\
(0.0322537)\end{array}$ & $\begin{array}{r}0.0210638 \\
(0.0166306)\end{array}$ & $\begin{array}{r}0.1600983^{* * *} \\
(0.0523666)\end{array}$ \\
\hline tfpgapel*rd & $\begin{array}{r}-0.0045931 \\
(0.0057473)\end{array}$ & $\begin{array}{r}-0.0016822 \\
(0.0066871)\end{array}$ & $\begin{array}{r}-0.0052252 \\
(0.0055910)\end{array}$ & $\begin{array}{r}-0.1163612 \\
(0.0713806)\end{array}$ & $\begin{array}{r}-0.0467809 \\
(0.0372730)\end{array}$ & $\begin{array}{r}-0.355386 * * * \\
(0.1159721)\end{array}$ \\
\hline rd*rdregional & $\begin{array}{r}-0.000000744^{* *} \\
(0.0000003)\end{array}$ & $\begin{array}{r}-0.0000001 \\
(0.0000002)\end{array}$ & $\begin{array}{r}-0.0000003 \\
(0.0000003)\end{array}$ & $\begin{array}{l}0.0000065^{*} \\
(0.0000039)\end{array}$ & $\begin{array}{r}0.0000026 \\
(0.0000019)\end{array}$ & $\begin{array}{r}0.0000205^{* * *} \\
(0.0000067)\end{array}$ \\
\hline Year dummies & Yes & Yes & Yes & Yes & Yes & Yes \\
\hline No obs & 514 & 415 & 432 & 693 & 557 & 579 \\
\hline No firms & 90 & 90 & 90 & 119 & 119 & 119 \\
\hline R-sq & 0.9856 & 0.6598 & & 0.9861 & 0.7378 & \\
\hline Hansen $J$ test & & & 49.94 & & & 0.146 \\
\hline $\begin{array}{l}\text { Arellano-Bond } \\
\text { test for AR (1) }\end{array}$ & & & 0.113 & & & 0.005 \\
\hline $\begin{array}{l}\text { Arellano-Bond } \\
\text { test for AR (2) }\end{array}$ & & & 0.271 & & & 0.409 \\
\hline
\end{tabular}


Table. 10

Romania low-tech clustered firms

\begin{tabular}{|c|c|c|c|c|c|c|}
\hline \multirow[b]{2}{*}{$\begin{array}{l}\text { Dependent } \\
\text { variable }\end{array}$} & \multicolumn{3}{|c|}{ Reverse spillovers } & \multicolumn{3}{|c|}{ Direct spillovers } \\
\hline & log Sales & $\Delta \log$ TFP & log Sales & log Sales & $\Delta \log$ TFP & log Sales \\
\hline $\begin{array}{l}\text { Estimation } \\
\text { method }\end{array}$ & OLS & $\begin{array}{l}\text { Levinsohn } \\
\text { and Petrin }\end{array}$ & GMM & OLS & $\begin{array}{l}\text { Levinsohn } \\
\text { and Petrin }\end{array}$ & GMM \\
\hline Inemp & $\begin{array}{r}0.3551484^{* * *} \\
(0.0112870)\end{array}$ & & $\begin{array}{r}0.3114823^{* * *} \\
(0.1020561)\end{array}$ & $\begin{array}{r}0.3212537 * * * \\
(0.0151905)\end{array}$ & & $\begin{array}{c}0.181245 * * \\
(0.0468361)\end{array}$ \\
\hline Inmaterial & $\begin{array}{r}0.6967174^{* * *} \\
(0.0232253)\end{array}$ & & $\begin{array}{r}0.5152161^{* * *} \\
(0.0827876)\end{array}$ & $\begin{array}{r}0.713349 * * * \\
(0.0299383)\end{array}$ & & $\begin{array}{r}0.6957212^{* *} \\
(0.0519743)\end{array}$ \\
\hline Incap & $\begin{array}{l}0.0233576^{*} \\
(0.0121207)\end{array}$ & & $\begin{array}{r}0.1643858^{* * *} \\
(0.0418856)\end{array}$ & $\begin{array}{r}0.0474666 * * * \\
(0.0108172)\end{array}$ & & $\begin{array}{r}0.0150819 \\
(0.0182985)\end{array}$ \\
\hline Ilnsales & & & $\begin{array}{r}0.2139025 \\
(0.1373760)\end{array}$ & & & $\begin{array}{r}0.1439008 * * \\
(0.0676065)\end{array}$ \\
\hline sp*rd & $\begin{array}{r}-0.0018014 \\
(0.0059639)\end{array}$ & $\begin{array}{r}0.0057093 \\
(0.0047736)\end{array}$ & $\begin{array}{r}-0.0114839^{*} \\
(0.0068733)\end{array}$ & $\begin{array}{r}0.0062254 \\
(0.0175921)\end{array}$ & $\begin{array}{r}0.0165855 \\
(0.0117837)\end{array}$ & $\begin{array}{r}0.0016025 \\
(0.0140751)\end{array}$ \\
\hline rdgap*sp & $\begin{array}{l}0.0090894^{*} \\
(0.0048418)\end{array}$ & $\begin{array}{r}-0.0015878 \\
(0.0040092)\end{array}$ & $\begin{array}{l}0.0124773^{*} \\
(0.0072889)\end{array}$ & $\begin{array}{r}0.0063105^{* * *} \\
(0.0005539)\end{array}$ & $\begin{array}{r}0.002422^{* * *} \\
(0.0007572)\end{array}$ & $\begin{array}{r}0.0024882^{* *} \\
(0.0006345)\end{array}$ \\
\hline tfpgap*sp & - & $\begin{array}{r}2.249387^{* * *} \\
(0.2972925)\end{array}$ & - & - & $\begin{array}{r}1.301423^{* * *} \\
(0.1604434)\end{array}$ & $\begin{array}{l}1.231061^{* *} \\
(0.2233619)\end{array}$ \\
\hline tfpgaploc*sp & $\begin{array}{l}2.40719 * * * \\
(0.3781355)\end{array}$ & -- & $\begin{array}{r}2.186273^{* * *} \\
(0.3763890)\end{array}$ & -- & -- & - \\
\hline tfpgapcl*sp & - & - & - & $\begin{array}{r}1.278157 * * * \\
(0.2171647)\end{array}$ & -- & - \\
\hline tfpgap*rd & $\begin{array}{l}0.0072684^{*} \\
(0.0039583)\end{array}$ & $\begin{array}{r}0.0052504 \\
(0.0032116)\end{array}$ & $\begin{array}{r}0.0020735 \\
(0.0038549)\end{array}$ & $\begin{array}{r}-0.0288980 \\
(0.0553164)\end{array}$ & $\begin{array}{r}-0.0645538 \\
(0.0398633)\end{array}$ & $\begin{array}{r}-0.0167290 \\
(0.0562101)\end{array}$ \\
\hline tfpgaploc*rd & $\begin{array}{r}0.0027202 \\
(0.0031667)\end{array}$ & $\begin{array}{r}0.0029996 \\
(0.0019435)\end{array}$ & $\begin{array}{r}0.0006512 \\
(0.0030016)\end{array}$ & $\begin{array}{r}-0.0627774 \\
(0.0699345)\end{array}$ & $\begin{array}{r}-0.0834639^{*} \\
(0.0496187)\end{array}$ & $\begin{array}{r}-0.0354753 \\
(0.0694429)\end{array}$ \\
\hline tfpgapcl*rd & $\begin{array}{r}-0.0101520 \\
(0.0065293)\end{array}$ & $\begin{array}{r}-0.0083448 \\
(0.0051585)\end{array}$ & $\begin{array}{r}-0.0027963 \\
(0.0066787)\end{array}$ & $\begin{array}{r}0.0910349 \\
(0.1250946)\end{array}$ & $\begin{array}{l}0.1478192^{*} \\
(0.0893073)\end{array}$ & $\begin{array}{r}0.0517059 \\
(0.1256284)\end{array}$ \\
\hline rd*rdregional & $\begin{array}{r}-0.0000012 \\
(0.0000008)\end{array}$ & $\begin{array}{r}-0.0000007 \\
(0.0000005)\end{array}$ & $\begin{array}{r}-0.0000001 \\
(0.0000007)\end{array}$ & $\begin{array}{r}-0.0000098 \\
(0.0000108)\end{array}$ & $\begin{array}{r}-0.0000117 \\
(0.0000073)\end{array}$ & $\begin{array}{r}-0.0000035 \\
(0.0000083)\end{array}$ \\
\hline Year dummies & Yes & Yes & Yes & Yes & Yes & Yes \\
\hline No obs & 2857 & 2151 & 2426 & 2180 & 1754 & 1853 \\
\hline No firms & 671 & 671 & 671 & 399 & 399 & 399 \\
\hline$R-s q$ & 0.9408 & 0.6335 & & 0.9638 & 0.7228 & \\
\hline Hansen J test & & & 0.614 & & & 0 \\
\hline $\begin{array}{l}\text { Arellano-Bond } \\
\text { test for AR (1) }\end{array}$ & & & 0.025 & & & 0.002 \\
\hline $\begin{array}{l}\text { Arellano-Bond } \\
\text { test for AR (2) }\end{array}$ & & & 0.756 & & & 0.008 \\
\hline
\end{tabular}


Table. 11

Romania high-tech non-clustered firms

\begin{tabular}{|c|c|c|c|c|c|c|}
\hline \multirow[b]{2}{*}{$\begin{array}{l}\text { Dependent } \\
\text { variable }\end{array}$} & \multicolumn{3}{|c|}{ Reverse spillovers } & \multicolumn{3}{|c|}{ Direct spillovers } \\
\hline & log Sales & $\Delta \log$ TFP & log Sales & log Sales & $\Delta \log$ TFP & log Sales \\
\hline $\begin{array}{l}\text { Estimation } \\
\text { method }\end{array}$ & oLs & $\begin{array}{r}\text { Levinsohn and } \\
\text { Petrin }\end{array}$ & GMM & OLS & $\begin{array}{r}\text { Levinsohn and } \\
\text { Petrin }\end{array}$ & GMM \\
\hline Inemp & $\begin{array}{r}0.1119101 * * * \\
(0.0312862)\end{array}$ & & $\begin{array}{r}-0.0455355 \\
(0.0707674)\end{array}$ & $\begin{array}{r}0.1317412^{* * *} \\
(0.0224363)\end{array}$ & & $\begin{array}{r}0.0214460 \\
(0.0543345)\end{array}$ \\
\hline Inmaterial & $\begin{array}{r}0.7074214^{* * *} * \\
(0.0284170)\end{array}$ & & $\begin{array}{r}0.2432383^{* *} \\
(0.1225980)\end{array}$ & $\begin{array}{r}0.6775937^{* * *} \\
(0.0250495)\end{array}$ & & $\begin{array}{r}0.4179472 * * * \\
(0.0677963)\end{array}$ \\
\hline Incap & $\begin{array}{r}0.1184678^{* * *} \\
(0.0311790)\end{array}$ & & $\begin{array}{r}0.0357467 \\
(0.0550325)\end{array}$ & $\begin{array}{l}0.0322745^{*} \\
(0.0179885)\end{array}$ & & $\begin{array}{r}-0.1423071^{* * *} \\
(0.0498912)\end{array}$ \\
\hline IInsales & & & $\begin{array}{r}0.605712^{* * * *} \\
(0.1336328)\end{array}$ & & & $\begin{array}{r}0.4803587 * * * \\
(0.0703864)\end{array}$ \\
\hline sp*rd & $\begin{array}{r}-0.0005502 \\
(0.0008196)\end{array}$ & $\begin{array}{r}-0.0004749 \\
(0.0006853)\end{array}$ & $\begin{array}{r}0.0002497 \\
(0.0006677)\end{array}$ & $\begin{array}{l}-0.0002096 \\
(0.0004184)\end{array}$ & $\begin{array}{r}0.0001913 \\
(0.0003108)\end{array}$ & $\begin{array}{r}0.0001146 \\
(0.0002235)\end{array}$ \\
\hline rdgap*sp & $\begin{array}{r}-0.0009999 * * * \\
(0.0003223)\end{array}$ & $\begin{array}{r}0.0010070 \\
(0.0006186)\end{array}$ & $\begin{array}{r}-0.0006083 \\
(0.0005423)\end{array}$ & $\begin{array}{r}-0.0000100 \\
(0.0000345)\end{array}$ & $\begin{array}{r}0.0000101 \\
(0.0000583)\end{array}$ & $\begin{array}{r}-0.0004273^{* * *} \\
(0.0001089)\end{array}$ \\
\hline tfpgap*sp & $\begin{array}{r}-0.0028893 \\
(0.0059047)\end{array}$ & $\begin{array}{r}-0.0423471^{* * *} \\
(0.0119013)\end{array}$ & $\begin{array}{r}0.0307838^{* *} \\
(0.0128951)\end{array}$ & $\begin{array}{r}0.0077981^{* * *} \\
(0.0015352)\end{array}$ & $\begin{array}{r}0.0283909 * * * \\
(0.0064990)\end{array}$ & $\begin{array}{r}-0.0007806 \\
(0.0031017)\end{array}$ \\
\hline tfpgaploc*sp & $\begin{array}{r}0.0062154 \\
(0.0061052)\end{array}$ & $\begin{array}{r}0.0596801^{* * * *} \\
(0.0126939)\end{array}$ & $\begin{array}{r}0.0265899 * * \\
(0.0129761)\end{array}$ & $\begin{array}{r}0.0017502^{* * *} \\
(0.0003239)\end{array}$ & $\begin{array}{r}-0.0032462^{* * *} \\
(0.0005291)\end{array}$ & $\begin{array}{r}0.0075372^{* * *} \\
(0.0021754)\end{array}$ \\
\hline tfpgapcl*sp & $\begin{array}{r}0.0000600 \\
(0.0000829)\end{array}$ & $\begin{array}{r}0.0002359^{* * *} \\
(0.0000837)\end{array}$ & $\begin{array}{r}0.0006799 * * * \\
(0.0001742)\end{array}$ & $\begin{array}{r}0.0000072 \\
(0.0000087)\end{array}$ & $\begin{array}{r}0.0000567^{* * *} \\
(0.0000092)\end{array}$ & $\begin{array}{r}0.0001365 * * * \\
(0.0000233)\end{array}$ \\
\hline tfpgap*rd & $\begin{array}{l}0.0000014^{*} \\
(0.0000007)\end{array}$ & $\begin{array}{c}-0.0000003^{*} \\
(0.0000002)\end{array}$ & $\begin{array}{r}0.0000003 \\
(0.0000003)\end{array}$ & $\begin{array}{r}0.00000286 * * \\
(0.0000014)\end{array}$ & $\begin{array}{r}0.00000582^{* * *} \\
(0.0000020)\end{array}$ & $\begin{array}{r}-0.00000158^{* *} \\
(0.0000007)\end{array}$ \\
\hline tfpgaploc*rd & $\begin{array}{l}-0.0000014^{*} \\
(0.0000007)\end{array}$ & $\begin{array}{r}0.000000348^{*} \\
(0.0000002)\end{array}$ & $\begin{array}{r}-0.0000003 \\
(0.0000003)\end{array}$ & $\begin{array}{r}0.0000019 \\
(0.0000012)\end{array}$ & $\begin{array}{r}0.00000287^{* *} \\
(0.0000011)\end{array}$ & $\begin{array}{r}0.00000127^{* *} \\
(0.0000006)\end{array}$ \\
\hline tfpgapel*rd & $\begin{array}{r}0.0000000 \\
(0.0000000)\end{array}$ & $\begin{array}{r}0.0000000 \\
(0.0000000)\end{array}$ & $\begin{array}{r}0.0000000 \\
(0.0000000)\end{array}$ & $\begin{array}{r}0.0000000 \\
(0.0000000)\end{array}$ & $\begin{array}{r}0.0000000 \\
(0.0000000)\end{array}$ & $\begin{array}{l}0.0000000 * \\
(0.0000006)\end{array}$ \\
\hline rd*rdregional & $\begin{array}{r}0.000000265^{* *} \\
(0.0000001)\end{array}$ & $\begin{array}{c}-0.0000001^{*} \\
(0.0000000)\end{array}$ & $\begin{array}{r}0.0000001 \\
(0.0000001)\end{array}$ & $\begin{array}{r}0.0000004 \\
(0.0000003)\end{array}$ & $\begin{array}{r}0.0000002 \\
(0.0000003)\end{array}$ & $\begin{array}{r}0.000000358^{* *} \\
(0.0000001)\end{array}$ \\
\hline Year dummies & Yes & Yes & Yes & Yes & Yes & Yes \\
\hline No obs & 1537 & 1306 & 1274 & 2116 & 1831 & 1767 \\
\hline No firms & 201 & 201 & 201 & 359 & 359 & 359 \\
\hline$R-s q$ & 0.918 & 0.1817 & & 0.9032 & 0.3554 & \\
\hline Hansen $J$ test & & & 0.109 & & & 0.107 \\
\hline $\begin{array}{l}\text { Arellano-Bond } \\
\text { test for AR (1) }\end{array}$ & & & 0.001 & & & 0 \\
\hline $\begin{array}{l}\text { Arellano-Bond } \\
\text { test for AR (2) }\end{array}$ & & & 0.371 & & & 0.275 \\
\hline
\end{tabular}

